\title{
External Parasites of Dairy Cattle ${ }^{1}$
}

P. E. Kaufman, P. G. Koehler and J. F. Butler²

\section{Flies}

Flies (Figure 4) are characterized by having one pair of wings. They have complete metamorphosis with egg, larva, pupa and adult stages in their life history. About 20 families of flies are of veterinary importance. One of the most challenging characteristics of flies is their behavior of being in contact with livestock for only short periods of time. Adequate control can sometimes be difficult since measures must applied at precisely the right time.

\section{Blood-Sucking Flies}

\section{Black Flies}

Black flies (Figure 1) are small, dark, stout-bodied flies with a humpbacked appearance. The adult females blood feed mainly during daylight hours and are not host specific. The black fly is a potential disease vector in Florida. It hovers about the eyes, ears and nostrils of animals, often alighting and puncturing the skin with an irritating bite. Large numbers of bites may cause weakness from blood loss, anaphylactic shock or death.

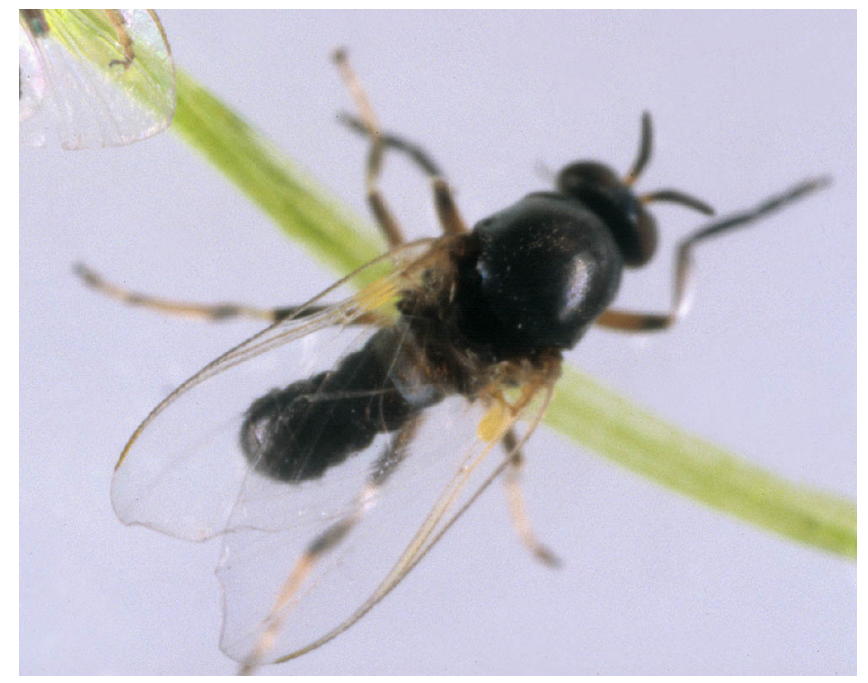

Figure 1. Black fly Credits: J. F. Butler, University of Florida

The black fly life cycle begins with eggs being deposited on logs, rocks or solid surfaces in eddies of flowing streams. Larvae attach themselves to rocks or vegetation with a posterior sucker or threads. The length of the larval period is quite variable depending on the species and the larval environment. The adults, which emerge after pupation, are strong fliers and may fly 7 to 10 miles from their breeding sites.

1. This document is ENY-251 (IG050), one of a series of the Entomology and Nematology Department, Florida Cooperative Extension Service, Institute of Food and Agricultural Sciences, University of Florida. Revised: March 2006. Please visit the EDIS Website at http://edis.ifas.ufl.edu.

2. P. E. Kaufman, assistant professor, P. G. Koehler, professor/extension entomologist, and J. F. Butler, retired professor, Entomology and Nematology Department, Cooperative Extension Service, Institute of Food and Agricultural Sciences, University of Florida, Gainesville, 32611.

The use of trade names in this publication is solely for the purpose of providing specific information. UF/IFAS does not guarantee or warranty the products named, and references to them in this publication does not signify our approval to the exclusion of other products of suitable composition. All chemicals should be used in accordance with directions on the manufacturer's label. 


\section{Horn Flies}

The horn fly (Figure 2) is one of the most serious pests of cattle in Florida. It causes pain, annoyance and interference with feeding, resting and other normal activities. The fly pierces the skin to blood feed and is a persistent biter. With high summertime populations, they cause cattle to lose weight and lower milk production. Horn flies may cause open sores on the head and underline, which can predispose the animals to secondary infection. Flies tend to cluster at preferred sites on the host (primarily the withers and back). Because of their piercing and sucking mouth parts, they are suspected of mechanically transmitting anaplasmosis and other diseases within the herd.

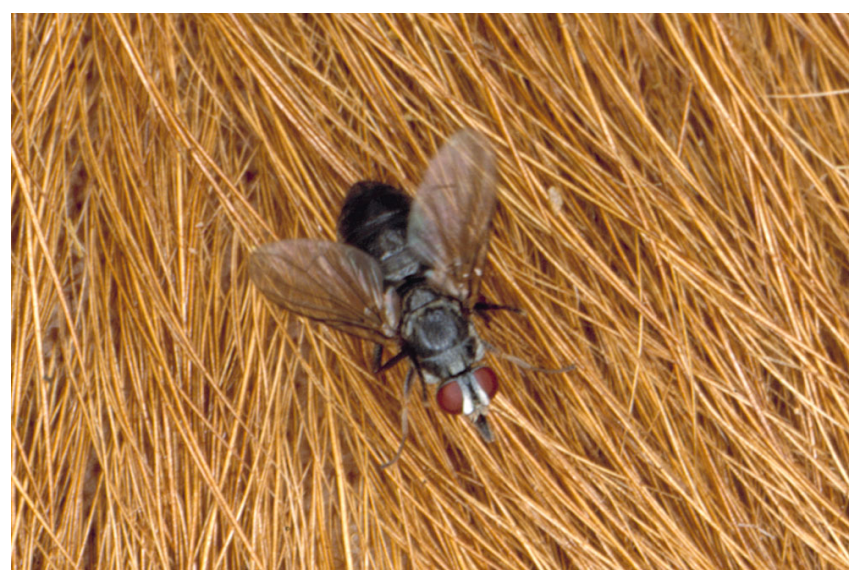

Figure 2. Horn fly Credits: J. F. Butler, University of Florida

Horn fly numbers of 50 or more per animal are considered to be of economic importance, although 10,000 to 20,000 per animal have been reported. Blood loss in these extreme cases can be considerable.

Eggs are laid exclusively in fresh (within 10 minutes of dropping) cattle manure. Larvae hatch in about 18 hours and feed on the dung, passing through 3 stages in 3 to 5 days. The pupal stage lasts 3 to 5 days, and the adults which emerge have a preoviposition period of 3 days. Mating takes place on the host, and females can lay about 200 eggs in their lifetime. The life cycle from egg to adult takes about 10 to 14 days.

The adults feed intermittently, perhaps 20 times a day, and remain on the host day and night, except for oviposition. This makes them susceptible to chemical control measures. Forced use dust bags give the best control of horn flies, although sprays, ear tags and dips may also be successfully used. Back rubbers and pour-on-materials can give control but are usually the least successful. Feed additives may be used for larval control; however, adult populations may not be affected when fly migration keeps populations at high levels.

\section{Horse and Deer Flies}

Horse flies (Figure 3) and deer flies (Figure 4), also called Tabanids, are insects that are usually strong fliers. As with mosquitoes, only females bite. They are usually daytime feeders and are vicious biters. Their attacks often account for lowered weight gains and lowered milk production. Because of their painful bites and frequent attacks, horse flies produce frenzied behavior in their hosts, sometimes causing them to run long distances in an effort to escape.

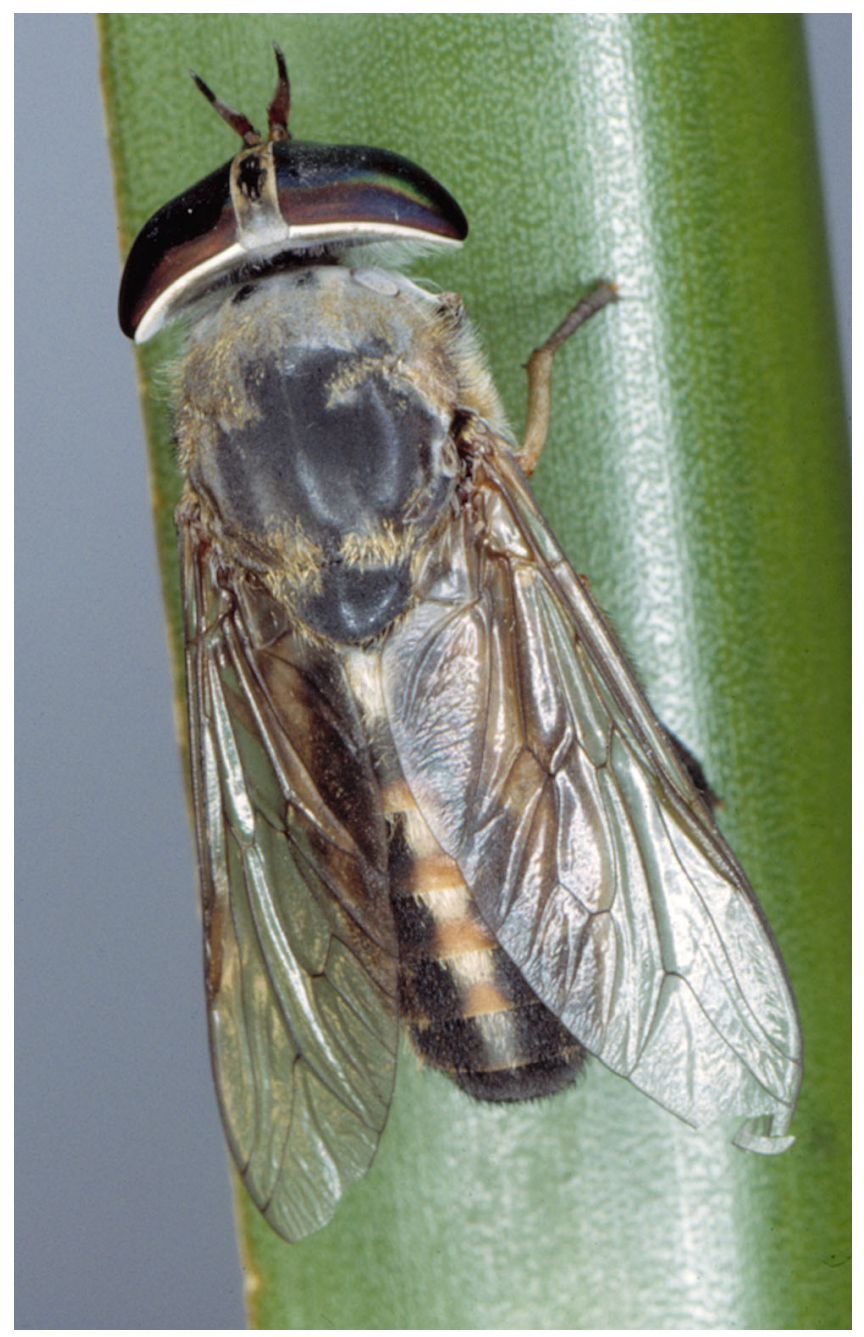

Figure 3. Horse fly Credits: J. F. Butler, University of Florida 


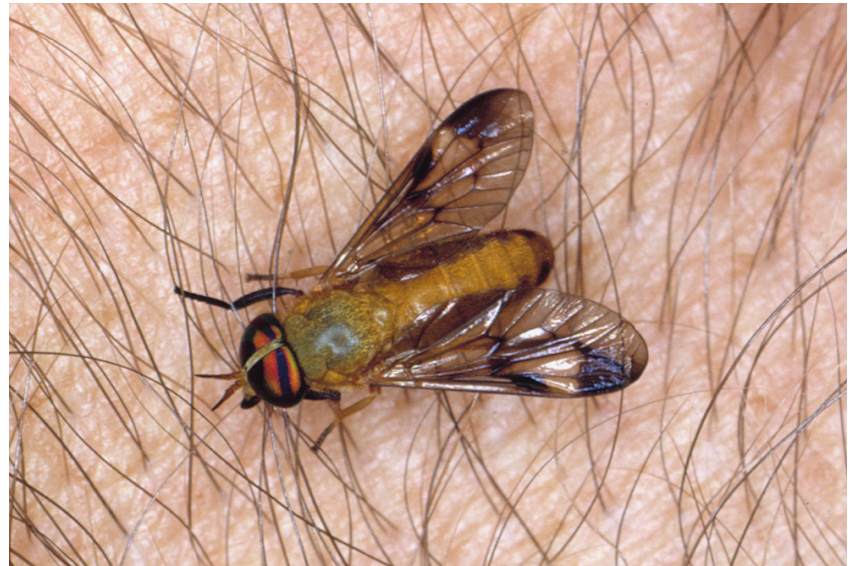

Figure 4. Deer fly Credits: James Castner, University of Florida

Tabanids introduce an anticoagulant into the wound when they bite that causes blood to ooze. These wounds are excellent sites for secondary invasion of other insects and diseases, and also cause more blood loss. Being intermittent feeders, they can be important mechanical transmitters of diseases such as anthrax, tularemia and anaplasmosis.

Most species of tabanids are aquatic or semi-aquatic in the immature stage, but some develop in moist soil, leaf mold or rotting logs. Generally the eggs are deposited in layers on vegetation, objects over water, or moist areas favorable to larval development. Eggs hatch in 5 to 7 days and the larvae fall to the surface of the water or moist areas where they begin to feed on organic matter.

Many species prey upon insect larvae, crustacea, snails and earthworms. When the larvae are ready to pupate, they move into drier soil, usually an inch or two below the surface. The pupal stage lasts 2 to 3 weeks, after which the adults emerge. The life cycle varies considerably between species, requiring anywhere from 70 days to 2 years. Florida has more than 122 kinds of horse and deer flies with some species present most times of the year. They are difficult pests to control. Daily mist applications will protect animals, but are difficult for most cattlemen to implement.

\section{Sand Flies and Biting Midges}

Sand flies (Figure 5) are small biting flies, also known as punkies, no-see-ums or biting midges. All these flies breed in wet or aquatic habitats and are a difficult, almost impossible, pest to control. These flies are predominately a source of annoyance and irritation, but may also cause suffocation because of large numbers. One species is a known vector of blue tongue virus in cattle and some are intermediate hosts of helminths. Little is known of the life cycle of those attacking livestock.

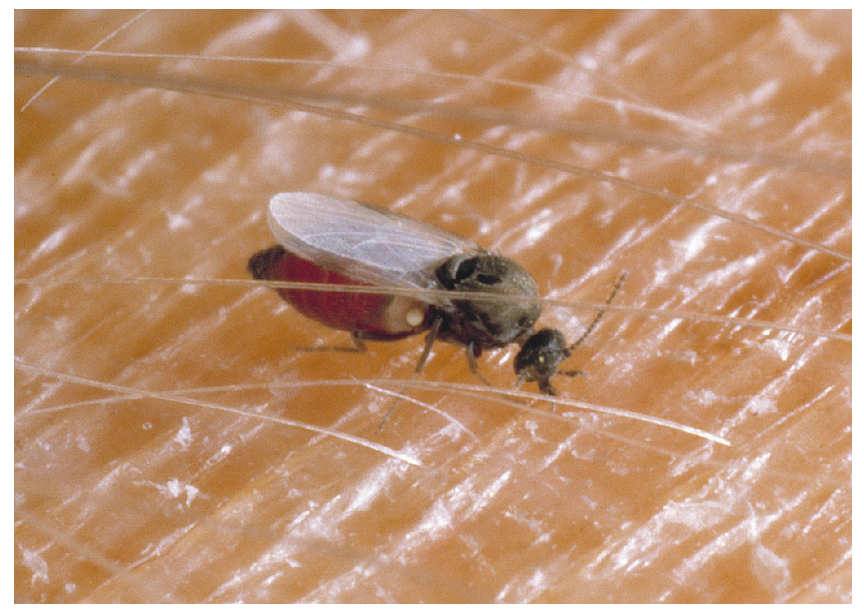

Figure 5. Sand fly Credits: J. F. Butler, University of Florida

\section{Stable Flies}

The stable fly (Figure 6), or dog fly, is similar to the house fly in size and color, but the bayonet-like mouthparts of the stable fly differentiate it from the house fly. Unlike the flies previously discussed, both sexes of the stable fly are vicious biters. They are strong fliers and range many miles from their breeding site.

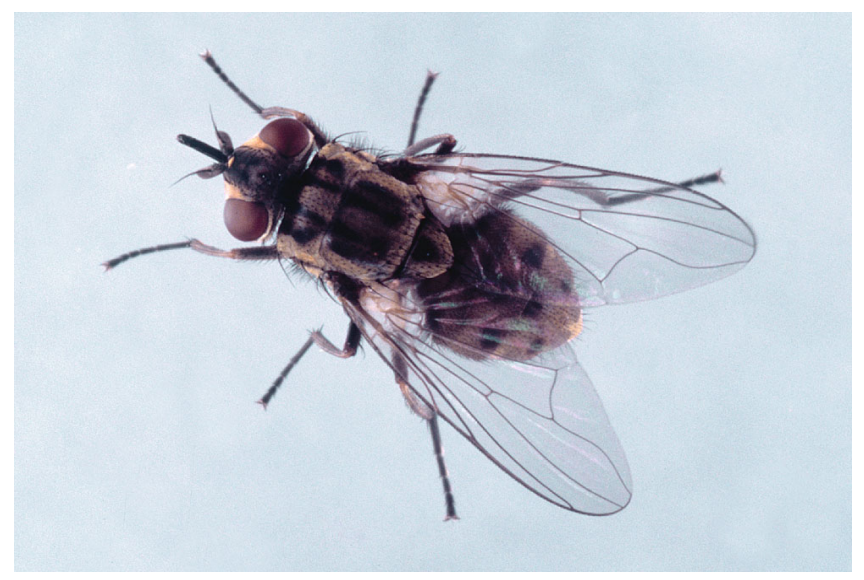

Figure 6. Stable fly Credits: J. F. Butler, University of Florida

Stable flies cause irritation and weakness in animals and account for much blood loss in severe cases. Bite wounds also can serve as sites for 
secondary infection. These flies are easily interrupted in feeding and are mechanical transmitters of anthrax and anaplasmosis.

Stable flies breed in soggy hay, grain or feed, piles of moist fermenting weed or grass cuttings, spilled green chop, peanut litter, seaweed deposits along beaches and in manure mixed with hay. The female, when depositing eggs, will often crawl into loose material, placing the eggs in little inner pockets. Each female may lay a total of 500 to 600 eggs in 4 separate layings. Eggs hatch in 2 to 5 days and the newly emerged larvae bury themselves, begin to feed, and mature in 14 to 26 days. While the average life cycle is 28 days, this period will vary from 22 to 58 days, depending on weather conditions.

Adult flies are capable of flying up to 80 miles from their breeding site. Greater than 10 flies per animal is considered economically damaging. Higher numbers indicate heavy fly breeding in the area.

Stable fly control is most successfully approached with cultural control measures. Since the larvae require a moist breeding media, it is essential that they breeding source be found and dispersed to allow drying. Animal treatments are limited to fogging or mist applications of insecticide.

\section{Non-Blood-Sucking Flies}

\section{Cattle Grubs}

Two species of cattle grubs are found in the United States, the common cattle grub and the northern cattle grub. The common cattle grub is found in Florida; however, the northern cattle grub is usually found only in cattle shipped into Florida from other states.

The common cattle grub (Figure 7) lays its eggs chiefly on the hair of cattle, attaching 5 to 15 eggs to a single hair. No pain is inflicted at the time of oviposition. In the spring (February, March, April, May) cattle gallop madly for water or shade to escape the northern cattle grub (gadding). It is apparently a reaction to the sound produced by the bee-like fly in flight.

Eggs hatch within 4 days, and the maggots burrow through the skin. Migration of the first stage

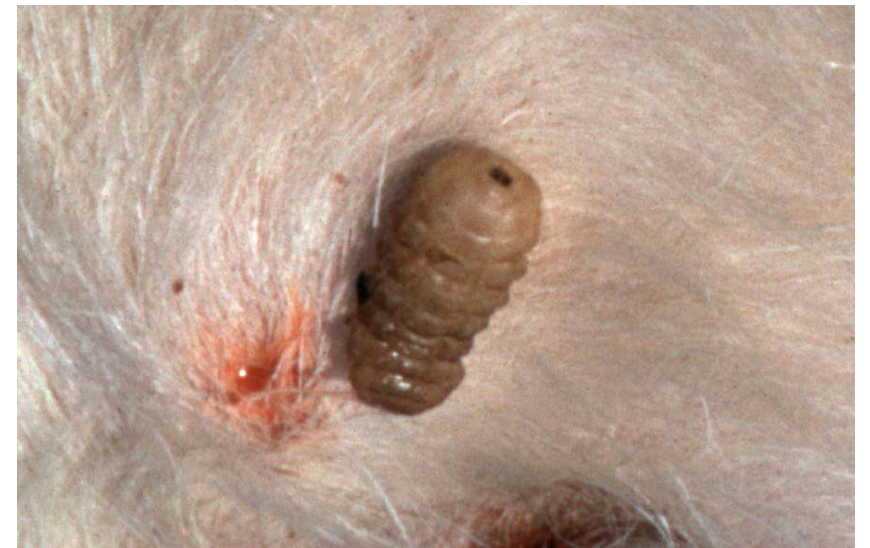

Figure 7. Cattle grub Credits: J. F. Butler, University of Florida

larvae of the common cattle grub is through connective tissue, assisted by enzyme secretion. Common cattle grub larvae locate in the mucous membrane of the gullet. Larvae of the northern cattle grub locate in the spinal cord. During the early fall in Florida (October-November), migrating first stage larvae begin reaching the backs of cattle where they cut or digest a breathing hole through the skin and form a warble.

First stage larvae molt in the warble formed in the back to the second stage in 3 to 4 days. The second stage larvae molts to the third stage then grows rapidly, feeding on pus, necrotic cells and secretions from the wall of the warble or cyst. One to 2 months are spent in the warble to attain full larval growth. The grub then squeezes through the breathing hole in the skin and drops to the ground to pupate. Pupation occurs in 2 to 3 days with the pupal stage lasting 20 to 60 days, depending on the temperature. The complete life cycle requires about a year.

The larvae produce two types of injury. First there is irritation caused by larval migrations in the body of the host and later by emergence from beneath the skin. Second, the escape of the larva from the warble leaves an open, running wound that is persistent and subject to secondary infection.

Economic losses are, however, much more important. Milk production may be reduced as much as 10 to 20 percent and loss of weight resulting from the wild efforts of the animals to escape from the flies may be considerable. The value of the carcass depreciates because flesh becomes greenish-yellow 
and jellylike in appearance and unfit for consumption where the grubs are located. The value of the hide is also reduced because of the holes cut in the skin.

Timing of treatments for control is important. The grubs must be killed before they reach the gullet or spinal cord, because killing grubs in these areas can cause swelling and possibly paralysis or death. "Cut-off dates" have been established in the United States for grub treatment. In Florida, grub appearance in the backs or gullets of animals occurs early, so the "cut-off date" has been set at August 31.

The treatment period includes that time after which egg hatch has ceased until larvae have moved up to, but not into, the back or gullet region. Sprays, dips, feed additives, and pour-ons are all recommended for cattle grub control although pour-ons give best results.

\section{Infestations of Fly Maggots (Myiasis)}

Myiasis is the presence of fly larvae in the living tissue of the host. Several kinds of maggots infest the wounds of warm-blooded animals; however, the only one that feeds exclusively on live flesh is the primary screwworm. Sterile male releases have eradicated the primary screwworm fly from the Southeast; but there is constant danger of reinfestation.

Other species such as the secondary screwworm and other blow flies may also infest wounds. These species normally lay their eggs on carcasses of dead animals and may occasionally occur in the dead tissue of open wounds. Although these species may cause some damage, they will not consume living flesh and will feed on dead flesh and wound secretions.

However, they may cause some tissue to die and then will feed on this dead tissue.

There is no simple way to differentiate between primary screwworms and other fly larvae. Any suspected screwworm case should be reported to the County Extension Director. Samples of eggs and maggots should be saved in a small container filled with $70 \%$ alcohol. Wounds should be treated with insecticidal ointment, sprays or dusts.

\section{Lice}

Most lice are permanent ectoparasites, spending their entire lives on the host. Both immature and adult stages are parasitic; therefore, they must remain on their hosts to survive. Each species of louse prefers a certain host. While a species may occur on several breeds of cattle, that same species will not occur on swine or horses. Most sucking lice are specific to the site they occupy on the host.

Five kinds of sucking lice (Figure 8) and one biting louse (Figure 9) are found on cattle in Florida. Sucking lice which feed on blood include the long-nosed cattle louse (found on the head, neck and brisket during winter to early spring), the short-nosed cattle louse (found on the head, neck and brisket during winter to early spring), and the cattle tail louse (the adults found principally in the tail brush and the immatures found on various parts of the body during summer to late fall and sometimes year round). The only biting louse, the cattle biting louse, feeds on skin and hair, causing itching, irritation and hair loss. It can be a severe problem in fall, winter or spring. Lice populations vary seasonally, depending largely on the condition of the host. The biting louse, and most sucking lice begin to increase in number during the fall and reach peak populations in late winter or early spring. Summer populations are usually minimal, causing no obvious symptoms. The host's "climate" may be extremely important. For example, skin temperature and moisture, quantity or thickness of hair, the amount of oil on the skin, and grooming behavior of the host may appreciably affect the size of the louse population. An animal under stress will usually support a larger louse population than is normal.

Lice are generally transmitted from one animal to another by contact. Transmission from herd to herd is usually accomplished by introduction of carrier animals, although some lice may move from place to place by clinging to flies (phoresy).

Feeding lice irritate host animals, and infestations may be recognized by animal behavior. Sucking lice pierce the host's skin and draw blood. Biting lice have chewing mouthparts and feed on particles of hair, scab and skin exudations. The 

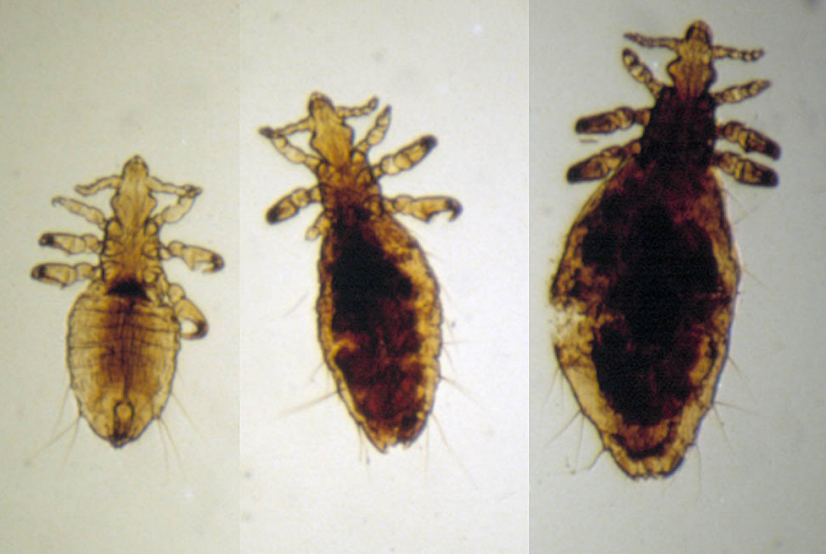

Figure 8. Long-nosed cattle louse (sucking louse). Credits: J. F. Butler, University of Florida

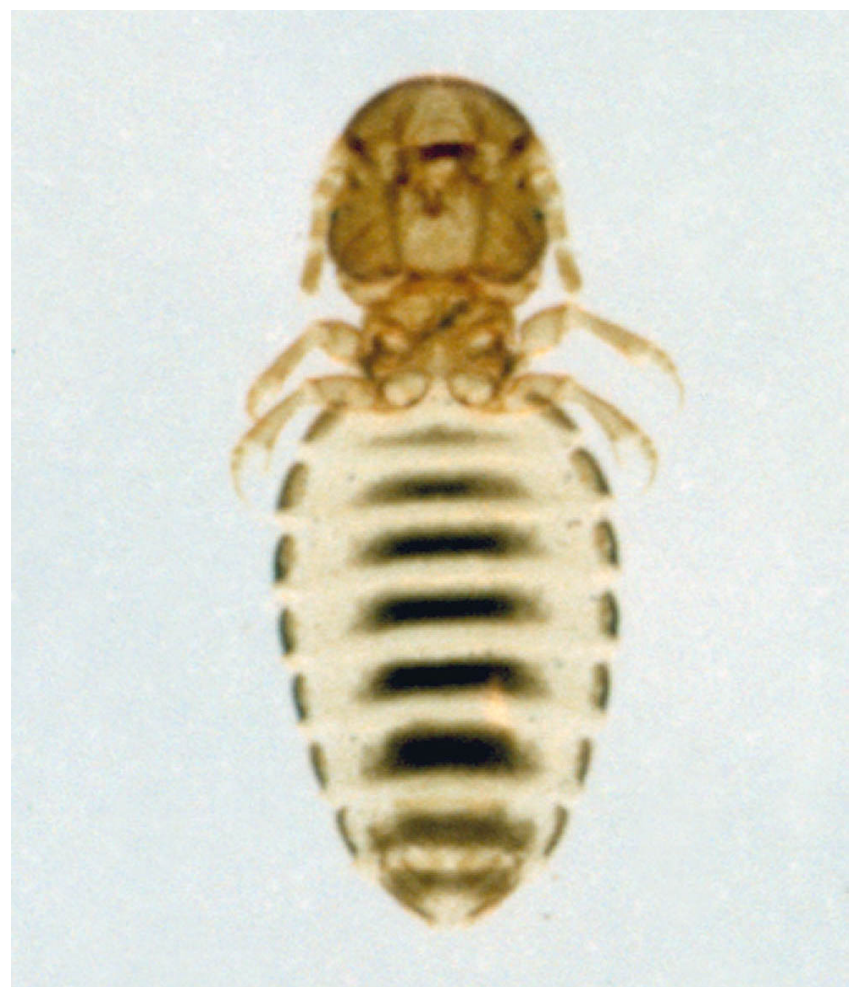

Figure 9. Biting louse Credits: J. F. Butler, University of Florida

irritation from louse-feeding causes animals to rub and scratch, producing raw areas on the skin or loss of hair. Weight loss may occur as a result of nervousness and improper nutrition. The host often is listless. In severe cases, blood loss to sucking lice can lead to anemia and may produce abortion.

Female lice glue their eggs to the hair of the host, close to the skin. The eggs hatch in 8 to 12 days, depending on the species and temperature. The nymphs go through 3 stages and are fully developed in about 3 weeks. The usual time from egg to egg-laying adult will be about 25 to 28 days.

Control of louse infestations is needed whenever an animal scratches and rubs to excess. Louse control is difficult since pesticides do not kill the louse egg. Since eggs of most species will hatch 8 to 12 days after pesticide application, retreatment is necessary 2 weeks after the first pesticide application. To prevent introduction of new louse infestations care should be taken to treat any new animal introduced into the herd.

Cattle tail lice are a special problem because eggs can survive and hatch up to 40 days after oviposition. A 3-week interval between treatments is recommended so most eggs will have hatched by the time the second application is made. The cattle tail louse (Figure 10) is a problem in the summer and fall seasons.

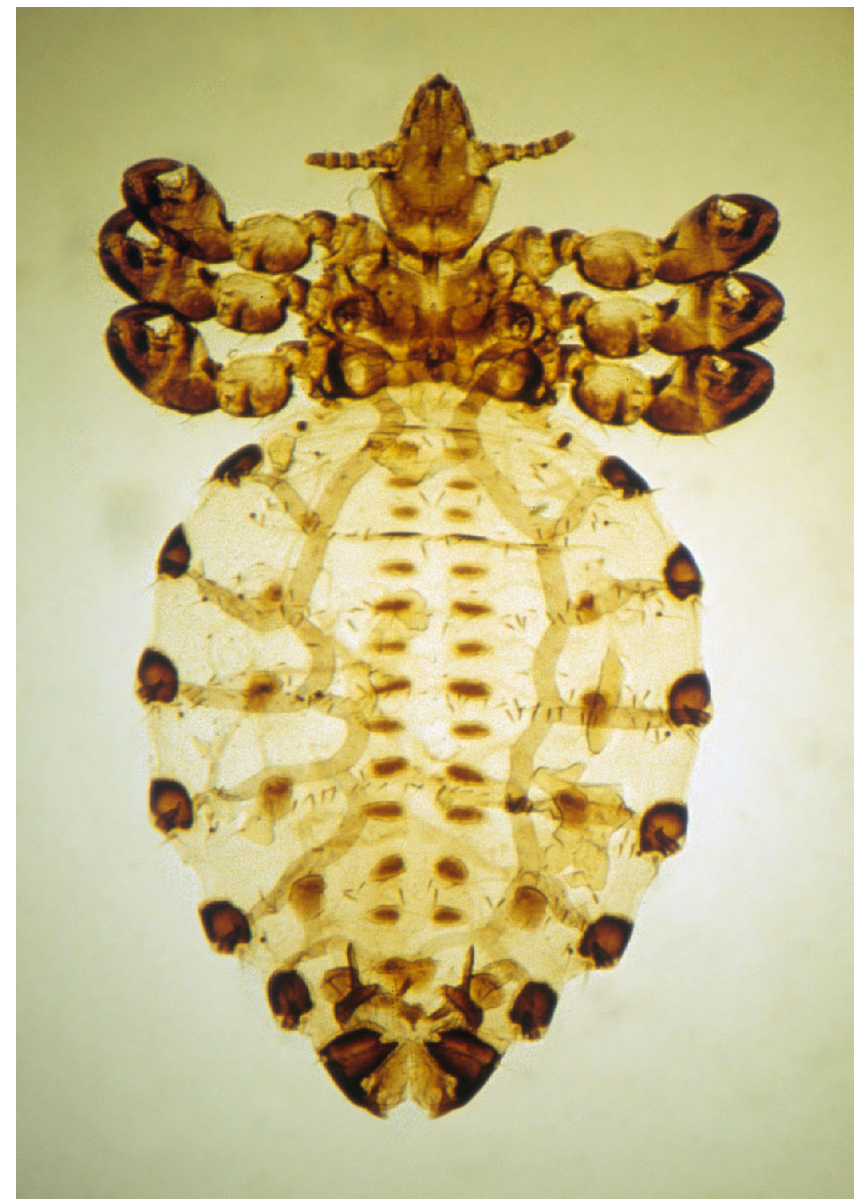

Figure 10. Cattle tail louse Credits: J. F. Butler, University of Florida 
The best control of lice is accomplished with forced use of dust bags. Residual sprays, dips and pour-on materials may also give satisfactory control.

\section{Mites}

Mites have the abdomen broadly joined to the thorax with little or no evidence of segmentation. Adults and nymphs generally have 8 legs and the larval stage has 6 . The life cycle of many species requires less than 4 weeks and in some it is as short as 8 days. All but a few species of mites are minute and barely visible to the naked eye.

Itch and mange mites (Figure 11) (Psoroptes, Sarcopte, and Chorioptes) feed on the surface or burrow just beneath the skin, making very slender, winding tunnels from 0.1 to $1 \mathrm{inch}$ long. The fluid discharged at the tunnel openings dries to form nodules. A toxin is also secreted which causes intense irritation and itching. Infested animals rub and scratch continuously, often producing inflamed areas with only scattered hairs remaining. The infection may spread over the entire body, forming large, cracked scabs on the thickened skin. Infestations are contagious and treatment of all animals in a herd is essential in preventing spread.

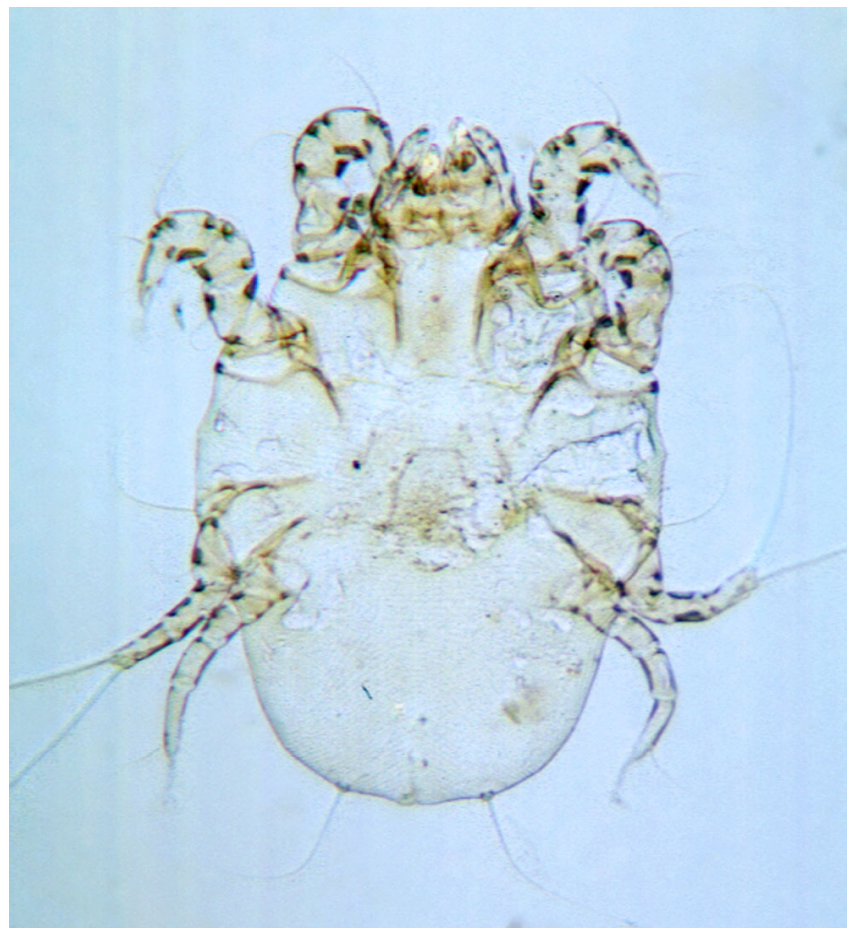

Figure 11. Itch mite Credits: J. L. Castner, University of Florida
Follicular mites are microscopic, cigar-shaped, worm-like organisms that live within the skin. All stages of the life cycle are found within the hair follicle. The mite causes nodular lesions in the skin which sometimes break, producing holes in the hide and opening the skin to secondary infection. Control is difficult because of the depth of penetration of the mites.

\section{Mosquitoes}

Mosquitoes (Figure 12) are small insects with piercing-sucking mouthparts, and scales on their wings. Female mosquitoes suck blood but do not always need blood to lay the first batch of eggs. Several species of mosquitoes attack livestock causing painful bites, unthriftiness, and occasionally death by suffocation or heavy blood loss. In addition, their attacks can cause loss of weight and decreased milk production.

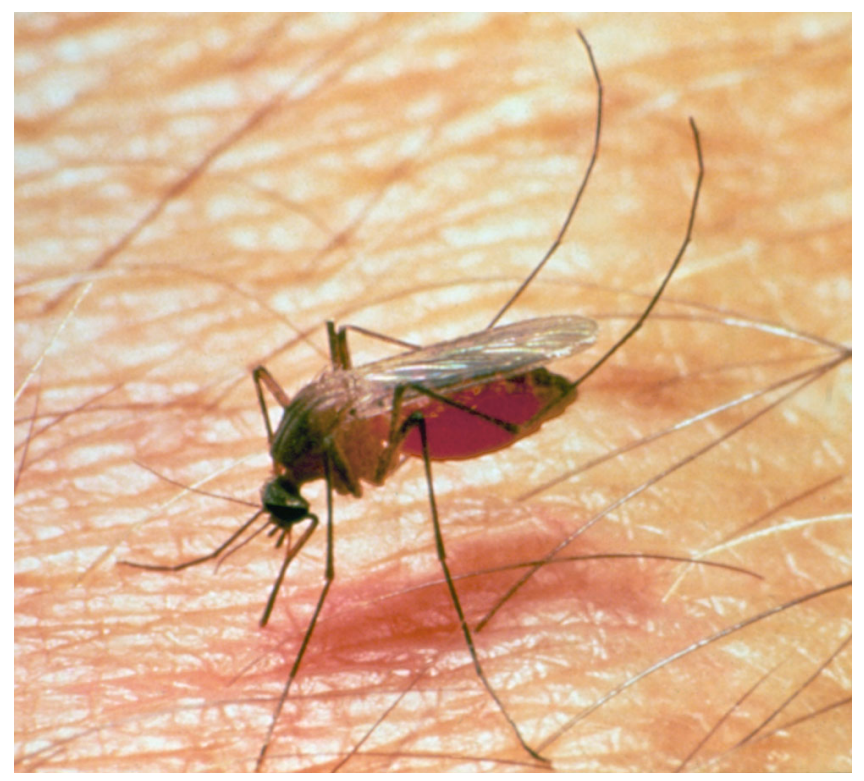

Figure 12. Mosquito Credits: J. F. Butler, University of Florida

The mosquito life cycle consists of 4 stages. The eggs are laid either directly on the water surface or on damp soil and sides of containers that will be flooded later. Common breeding sites for mosquitoes are drainage ditches, ponds, tin cans, old tires and tree holes. The eggs of most species hatch in 2 to 3 days, and the larvae or "wigglers" feed in the water on organic matter. The larvae pass through 4 stages in about 7 to 10 days. The pupal stage lasts 2 to 3 days, 
and the adult emerges from the pupal skin at the water surface.

If mosquitoes are a serious problem to livestock in your area, control measures should be implemented. The most effective control method available is source reduction by removing or draining mosquito breeding sites. Daily fogging or aerosoling for adult mosquitoes may provide relief but only as temporary control measure.

\section{Ticks}

Ticks (Figure 13) are easily distinguished from insects, since the body is not definitely divided and the strong fusion of the thorax and abdomen produces a sac-like, leathery appearance. A distinct head is lacking, but there is a head-like structure which bears recurved teeth that are inserted into the wound, allowing the tick to hold on strongly. Females can be greatly distended and are bean-like in form when fully engorged. Ticks have 4 developmental stages: egg, 6-legged seed or larval stage, 8-legged nymphal stage and 8-legged adult.

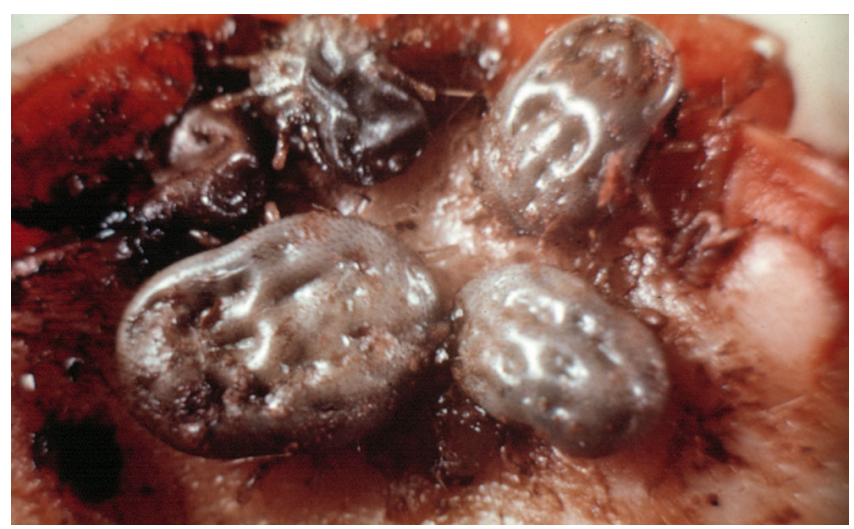

Figure 13. Ear ticks feeding. Credits: J. F. Butler, University of Florida

A fully engorged female usually deposits eggs (from 100 to 18,000) on the ground. The larval or seed ticks emerging from eggs in the soil usually climb up grasses or other low vegetation to contact passing animals. The larvae molt into nymphs and go through 3 to 5 nymphal stages (soft ticks 2-5). Ticks (Figure 14) remain in the 8-legged form in both nymphal and adult stages. The majority drop off the host to molt after feeding. Males, females and immatures all feed on blood and lymph.

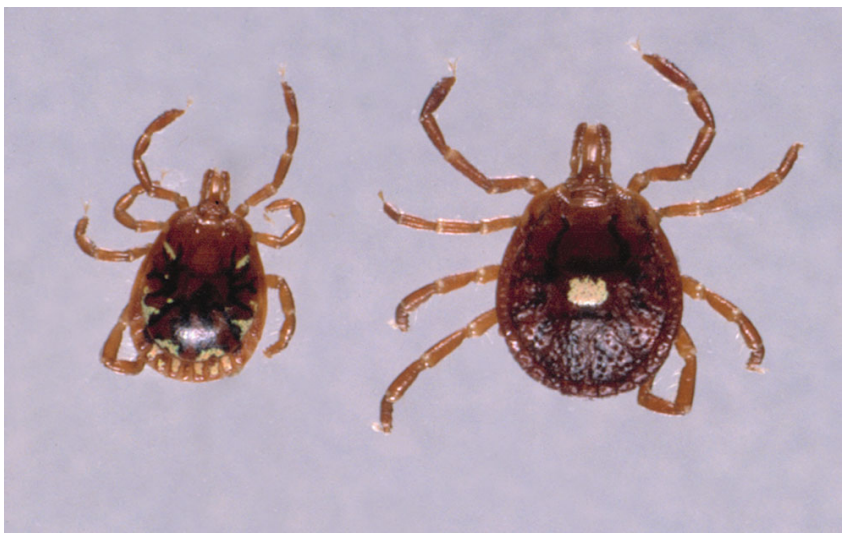

Figure 14. Lone Star tick Credits: J. F. Butler, University of Florida

The effects of ticks upon the host include inflammation, itching and swelling at the bite site, blood loss, production of wounds that may serve as sites for secondary invasion, obstruction of body openings and paralysis from the injection of toxic fluids. They also transmit many diseases, including anaplasmosis, bovine piroplasmosis and tularemia. Some ticks have the ability to transmit diseases to their offspring without feeding on a diseased animal.

Tick control may be attempted through premise control with insecticides. Premise control kills ticks which are either engorged or on foliage waiting to contact a host. On animals, tick control is best achieved with insecticide sprays or dips.

\section{Keys to Pesticide Safety}

1. Before using any pesticide, stop and read the precautions.

2. Read the label on each pesticide container before each use. Heed all warnings and precautions.

3. Store all pesticides in their original containers away from food or feed.

4. Keep pesticides out of the reach of children, pets and livestock.

5. Apply pesticides only as directed.

6. Dispose of empty containers promptly and safely.

Recommendations in this guide are for guidelines only. The user must insure that the 
pesticide is applied in strict compliance with label directions.

The Food and Drug Administration has established residue tolerances for certain insecticides in the meat of certain animals. When these and other approved insecticides are applied according to recommendations, the pests should be effectively controlled and the animals' products will be safe for food.

The improper use of insecticides may result in residue in milk or meat. Such products must not be delivered to processing plants. To avoid excessive residues, use the insecticides recommended at the time recommended and in the amounts recommended.

\section{Selected References}

Broce, A. B. 1988. An improved Alsynite trap for stable flies Stomoxys calcitrans (Diptera: Muscidae). J. Med. Entomol. 25: 406-409.

Catts, E. P and G. R. Mullen. 2002. Myiasis (Muscoidea, Oestroidea), In: Medical and Veterinary Entomology, (G. R. Mullen and L. A. Durden, Eds.), pp. 318-348. Elsevier Science, San Diego, CA.

Geden, C. J. and D. A. Rutz. 1988. Cattle lice are more than a winter problem. St. Lawrence Cty. Coop. Ext. News 72: 7, ill.

George, J. E., R. B. Davey, and J. M. Pound. 2002. Introduced ticks and tick-borne diseases: the threat and approaches to eradication. Vet. Clin. Food Anim. 18: 401-416.

Hogsette, J. A., and J. P. Ruff. 1985. Stable fly (Diptera: Muscidae) migration in Northwest Florida. Environ. Entomol. 14: 170-175.

Holste, J. E., D. D. Colwell, R. Kumar, J. E. Lloyd, N. P. M. Pinkall, M. A. Sierra, J. W. Waggoner, W. K. Langholff, R. A. Barrick, and J. S. Eagleson. 1998. Efficacy of eprinomectin against Hypoderma spp. in cattle. Am. J. Ver. Res. 59: 56-58.

Jones, C. J., J. A. Hogsette, R. S. Patterson, D. E. Milne, G. D. Propp, J. F. Milio, L. G. Rickard and J. P. Ruff. 1991. Origin of stable flies (Diptera:
Muscidae) on West Florida beaches: Electrophoretic analysis of dispersal. J. Med. Entomol. 28: 787-795.

Lysyk, T. J. and R. C. Axtell. 1986. Movement and distribution of house flies (Diptera: Muscidae) between habitats in two livestock farms. J. Econ. Entomol. 76: 993-998.

Masten, S. J., H. Kim-Yang, E. D. Walker, H. Roman, and M. T. Yokoyama. 2001. Toxicity of ozonated animal manure to the house fly, Musca domestica. J. Environ. Qual. 30: 1624-1630.

Matthysse, J. G. 1946. Cattle lice: Their biology and control, pp. 1-67. Cornell University Agricultural Experiment Station, Ithaca, NY.

Moon, R. D. 2002. Muscoid flies (Muscidae), In: Medical and Veterinary Entomology, (G. R. Mullen and L. A. Durden, Eds.), pp.45-65. Elsevier Science, San Diego, CA.

Mullens, B. A., A. C. Gerry, and R. K. Velten. 2001. Failure of a permethrin treatment regime to protect cattle against Bluetongue virus. J. Med. Entomol. 38: 760-762.

Nelson W. A., J. E. Keirans, J. F. Bell and C. M. Clifford. 1975. Review article host-ectoparasite relationships. J. Med. Entomol. 12: 143-166.

Pickens, L. G., E. T. Schmidtmann, and R. W. Miller. 1994. How to control house and stable flies without using pesticides, pp. 1-14. USDA, Washington, DC.

Rochon, K., T. J. Lysyk, and L. B. Selinger. 2004. Persistence of Escherichia coli in immature house fly and stable fly (Diptera: Muscidae) in relation to larval growth and survival. J. Med. Entomol. 41: 1082-1089.

Schmidtmann, E. T. 1985. Arthropod pests of dairy cattle. In: Livestock Entomology (R. E. Williams, R. D. Hall, A. B. Broce and P. J. Scholl, eds.), pp. 223-238. Wiley, New York.

Scholl P. J. 1993. Biology and control of cattle grubs. Annu. Rev. Entomol. 39: 53-70. 
Scott, J. G., R. T. Roush and D. A. Rutz. 1989. Insecticide resistance of house flies from New York dairies (Diptera: Muscidae). J. Agric. Entomol. 6: 53-64, maps.

Skoda S. R., J. B. Campbell, S. E. Kunz. 1987. Wide-area treatment of cattle for horn flies and face flies (Diptera: Muscidae) in South-central Nebraska. J. Econ. Entomol. 80: 811-816.

Steelman C. D., R. W. McNew, R. B. Simpson, R. W. Rorie, J. M. Phillips and C. F. Rosenkrans, Jr. 2003. Evaluation of alternative tactics for management of insecticide-resistant horn flies (Diptera: Muscidae). J. Econ. Entomol. 96: 892-901.

Steinkraus, D. C., C. J. Geden and D. A. Rutz. 1993. Prevalence of Entomophthora muscae (Cohn) Fresenius (Zygomycetes: Entomophthoraceae) in house flies (Diptera: Muscidae) on dairy farms in New York and induction of epizootics. Biol. Cont. 3: 93-100.

Tarry D. W. 1985. Cattle fly control using controlled-release insecticides. Vet. Parasit. 18: 229-234.

Watson, D. W., J. D. Lloyd, and R. Kumar. 1997. Density and distribution of cattle lice (Phthiraptera: Haematopinidae, Linognathidae, Trichodectidae) on six steers. Vet. Parasit. 69: 283-296.

Watson D. W., S. M. Stringham, S. S. Dennings, S. P. Washburn, M. H. Poore and A. Meier. 2002. Managing the horn fly (Diptera: Muscidae) using an electric walk-through fly trap. J. Econ. Entomol. 95: 1113-1118. 
Table 1. Summary of Dairy Cattle Insecticide Registrations.

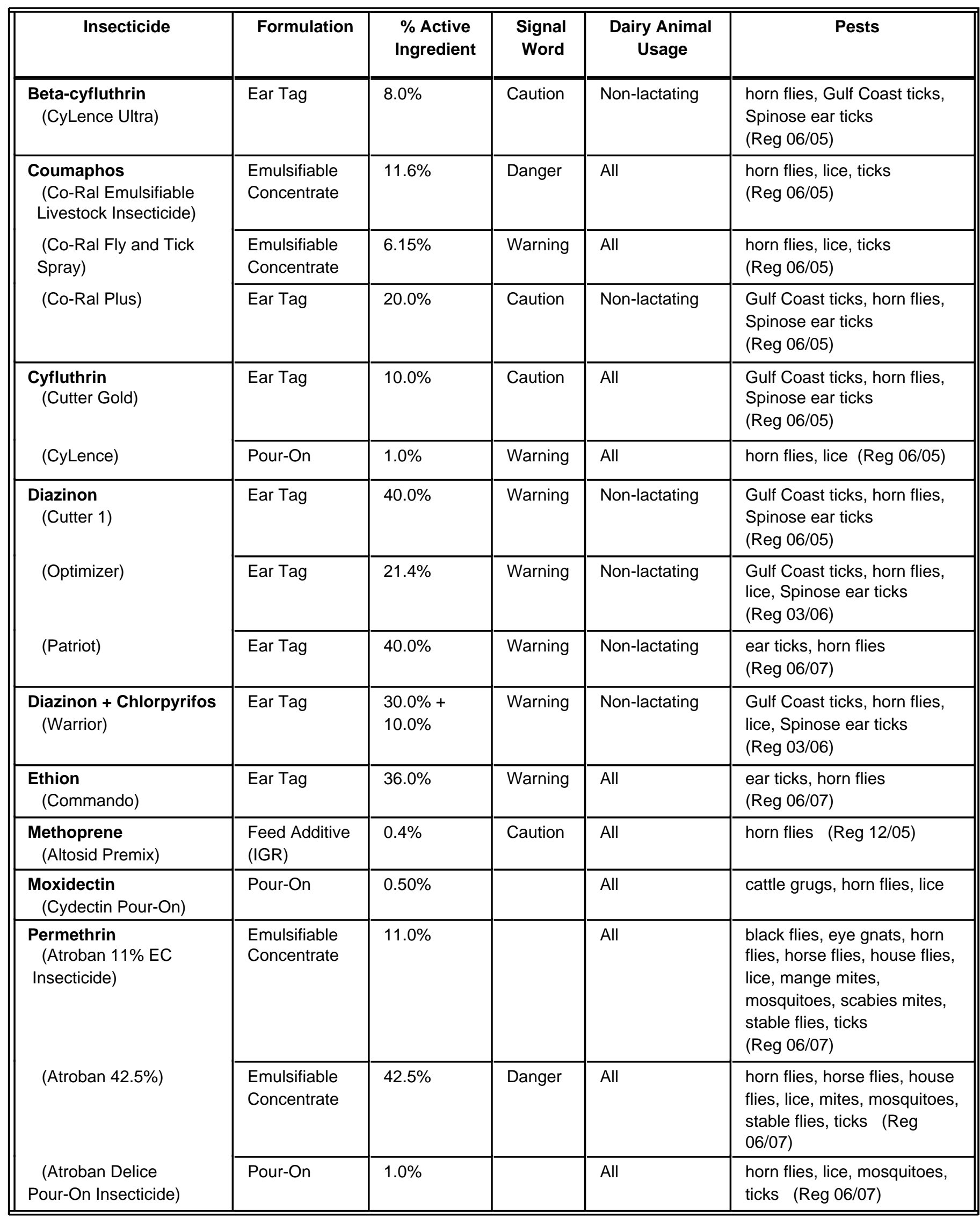


Table 1. Summary of Dairy Cattle Insecticide Registrations.

\begin{tabular}{|c|c|c|c|c|c|}
\hline Insecticide & Formulation & $\begin{array}{l}\% \text { Active } \\
\text { Ingredient }\end{array}$ & $\begin{array}{l}\text { Signal } \\
\text { Word }\end{array}$ & $\begin{array}{l}\text { Dairy Animal } \\
\text { Usage }\end{array}$ & Pests \\
\hline \multirow{3}{*}{$\begin{array}{l}\text { (Boss Pour-On } \\
\text { Insecticide) } \\
\text { (Brute Insecticide for } \\
\text { Cattle) } \\
\text { (Catron IV) }\end{array}$} & Pour-On & $5.0 \%$ & & All & horn flies, lice (Reg 06/07) \\
\hline & $\begin{array}{l}\text { Ready-To- } \\
\text { Use-Liquid }\end{array}$ & $10.0 \%$ & Warning & All & horn flies, lice (Reg 06/06) \\
\hline & Aerosol & $0.5 \%$ & Caution & All & $\begin{array}{l}\text { deer flies, horn flies, horse } \\
\text { flies, house flies, gnats, } \\
\text { screwworms (Reg 06/07) }\end{array}$ \\
\hline (GardStar 40\% EC) & $\begin{array}{l}\text { Emulsifiable } \\
\text { Concentrate }\end{array}$ & $40.0 \%$ & Danger & All & $\begin{array}{l}\text { black flies, deer flies, eye } \\
\text { gnats, horn flies, horse flies, } \\
\text { house flies, lice, mange } \\
\text { mites, mosquitoes, scabies } \\
\text { mites, stable flies, ticks } \\
\text { (Reg 03/06) }\end{array}$ \\
\hline (GardStar Plus) & Ear Tag & $10.0 \%$ & Caution & All & $\begin{array}{l}\text { Gulf Coast ticks, horn flies, } \\
\text { Spinose ear ticks } \\
\text { (Reg 03/06) }\end{array}$ \\
\hline (Permectrin II) & $\begin{array}{l}\text { Emulsifiable } \\
\text { Concentrate }\end{array}$ & $10.0 \%$ & Caution & All & $\begin{array}{l}\text { horn flies, horse flies, lice, } \\
\text { mites, mosquitoes, stable } \\
\text { flies, ticks (Reg 06/07) }\end{array}$ \\
\hline (Ultra Boss Pour-On) & Pour-On & $5.8 \%$ & & All & $\begin{array}{l}\text { horn flies, lice } \\
\text { (Reg 06/07) }\end{array}$ \\
\hline \multirow[t]{2}{*}{$\begin{array}{l}\text { Permethrin (Synergized) } \\
\text { (Permectrin CDS) }\end{array}$} & Pour-On & $7.4 \%$ & Caution & All & horn flies, lice (Reg 06/07) \\
\hline & Pour-On & $1.0 \%$ & & All & horn flies, lice (Reg 06/07) \\
\hline \multirow{2}{*}{$\begin{array}{l}\text { Phosmet } \\
\text { (Delphos } \\
\text { Emulsifiable Liquid) } \\
\text { (Prolate/Lintox-HD) }\end{array}$} & $\begin{array}{l}\text { Emulsifiable } \\
\text { Concentrate }\end{array}$ & $11.6 \%$ & & All & $\begin{array}{l}\text { Gulf Coast ear ticks, horn } \\
\text { flies, lice, Lone Star ticks, } \\
\text { sarcoptic mange, winter ticks } \\
\text { (Reg 06/07) }\end{array}$ \\
\hline & $\begin{array}{l}\text { Emulsifiable } \\
\text { Concentrate }\end{array}$ & $11.75 \%$ & Danger & Non-lactating & $\begin{array}{l}\text { horn flies, lice ticks } \\
\text { (Reg 12/05) }\end{array}$ \\
\hline \multirow{2}{*}{$\begin{array}{l}\text { Tetrachlorvinphos } \\
\text { (Rabon 7.76 Oral } \\
\text { Larvacide Premix) } \\
\text { (Ravap E.C.) }\end{array}$} & Feed Additive & $7.76 \%$ & Caution & All & $\begin{array}{l}\text { horn flies, house flies, stable } \\
\text { flies (Reg 03/07) }\end{array}$ \\
\hline & $\begin{array}{l}\text { Emulsifiable } \\
\text { Concentrate }\end{array}$ & $23.0 \%$ & Danger & All & $\begin{array}{l}\text { gnats, horn flies, lice, ticks } \\
\text { (Reg 09/06) }\end{array}$ \\
\hline \multirow[t]{2}{*}{$\begin{array}{l}\text { Zeta-cypermethrin } \\
\text { (Python) }\end{array}$} & Ear Tag & $10.0 \%$ & Caution & All & $\begin{array}{l}\text { Gulf Coast ticks, horn flies, } \\
\text { lice, Spinose ear ticks } \\
\text { (Reg 03/06) }\end{array}$ \\
\hline & Dust & & Caution & All & $\begin{array}{l}\text { horn flies, keds, lice, ticks } \\
\text { (Reg 03/06) }\end{array}$ \\
\hline
\end{tabular}


Table 2. Registered Insecticides for Specific Pests of Dairy Cattle.

\begin{tabular}{|c|c|c|c|}
\hline Insectcide & Formulation & $\begin{array}{l}\text { Re-Treatment } \\
\text { Interval }\end{array}$ & Comments \\
\hline $\begin{array}{l}\text { Atroban } 11 \% \text { EC Insecticide } \\
\text { (permethrin) }\end{array}$ & $\begin{array}{l}\text { Emulsifiable } \\
\text { Concentrate }\end{array}$ & 2 weeks & $\begin{array}{l}\text { Mix thoroughly according to label directions. } \\
\text { Spray lactating animals only after milking is } \\
\text { completed. (Reg 06/07) }\end{array}$ \\
\hline $\begin{array}{l}\text { GardStar } 40 \% \text { EC } \\
\text { (permethrin) }\end{array}$ & $\begin{array}{l}\text { Emulsifiable } \\
\text { Concentrate }\end{array}$ & 10-14 days & $\begin{array}{l}\text { Dilute and apply according to label directions. } \\
\text { May be used as a high pressure spray, low } \\
\text { pressure spray (hand-pump sprayer), or } \\
\text { backrubber. (Reg 03/06) }\end{array}$ \\
\hline \multicolumn{4}{|c|}{ Deer Flies } \\
\hline $\begin{array}{l}\text { Catron IV } \\
\text { (permethrin) }\end{array}$ & Aerosol & & Spray according to label directions. (Reg 06/07) \\
\hline $\begin{array}{l}\text { GardStar } 40 \% \text { EC } \\
\text { (permethrin) }\end{array}$ & $\begin{array}{l}\text { Emulsifiable } \\
\text { Concentrate }\end{array}$ & $10-14$ days & $\begin{array}{l}\text { Dilute and apply according to label directions. } \\
\text { May be used as a high pressure spray, low } \\
\text { pressure spray (hand-pump sprayer), or } \\
\text { backrubber. (Reg 03/06) }\end{array}$ \\
\hline $\begin{array}{l}\text { GardStar } 40 \% \text { EC } \\
\text { (permethrin) }\end{array}$ & $\begin{array}{l}\text { Emulsifiable } \\
\text { Concentrate }\end{array}$ & 10-14 days & $\begin{array}{l}\text { Dilute and apply according to label directions. } \\
\text { May be used as a high pressure spray, low } \\
\text { pressure spray (hand-pump sprayer), or } \\
\text { backrubber. (Reg 03/06) }\end{array}$ \\
\hline \multicolumn{4}{|c|}{ Horn Flies } \\
\hline $\begin{array}{l}\text { Altosid Premix } \\
\text { (methoprene) }\end{array}$ & $\begin{array}{l}\text { Feed Additivive } \\
(\mathrm{IGR})\end{array}$ & & $\begin{array}{l}\text { Begin use in the spring before horn flies appear } \\
\text { on cattle and continue feeding until cold weather } \\
\text { restricts horn fly activity. Mix with feed or minerals } \\
\text { at the rate recommended on the label. } \\
\text { (Reg } 12 / 05)\end{array}$ \\
\hline $\begin{array}{l}\text { Atroban } 11 \% \text { EC Insecticide } \\
\text { (permethrin) }\end{array}$ & $\begin{array}{l}\text { Emulsifiable } \\
\text { Concentrate }\end{array}$ & 2 weeks & $\begin{array}{l}\text { Mix thoroughly according to label directions. } \\
\text { Spray lactating animals only after milking is } \\
\text { completed. (Reg 06/07) }\end{array}$ \\
\hline $\begin{array}{l}\text { Atroban } 42.5 \% \text { EC } \\
\text { (permethrin) }\end{array}$ & $\begin{array}{l}\text { Emulsifiable } \\
\text { Concentrate }\end{array}$ & 10 to 14 days & $\begin{array}{l}\text { Apply diluted product, according to label } \\
\text { directions as a dip or spray. Do not use in milk } \\
\text { rooms. (Reg 06/07) }\end{array}$ \\
\hline
\end{tabular}


Table 2. Registered Insecticides for Specific Pests of Dairy Cattle.

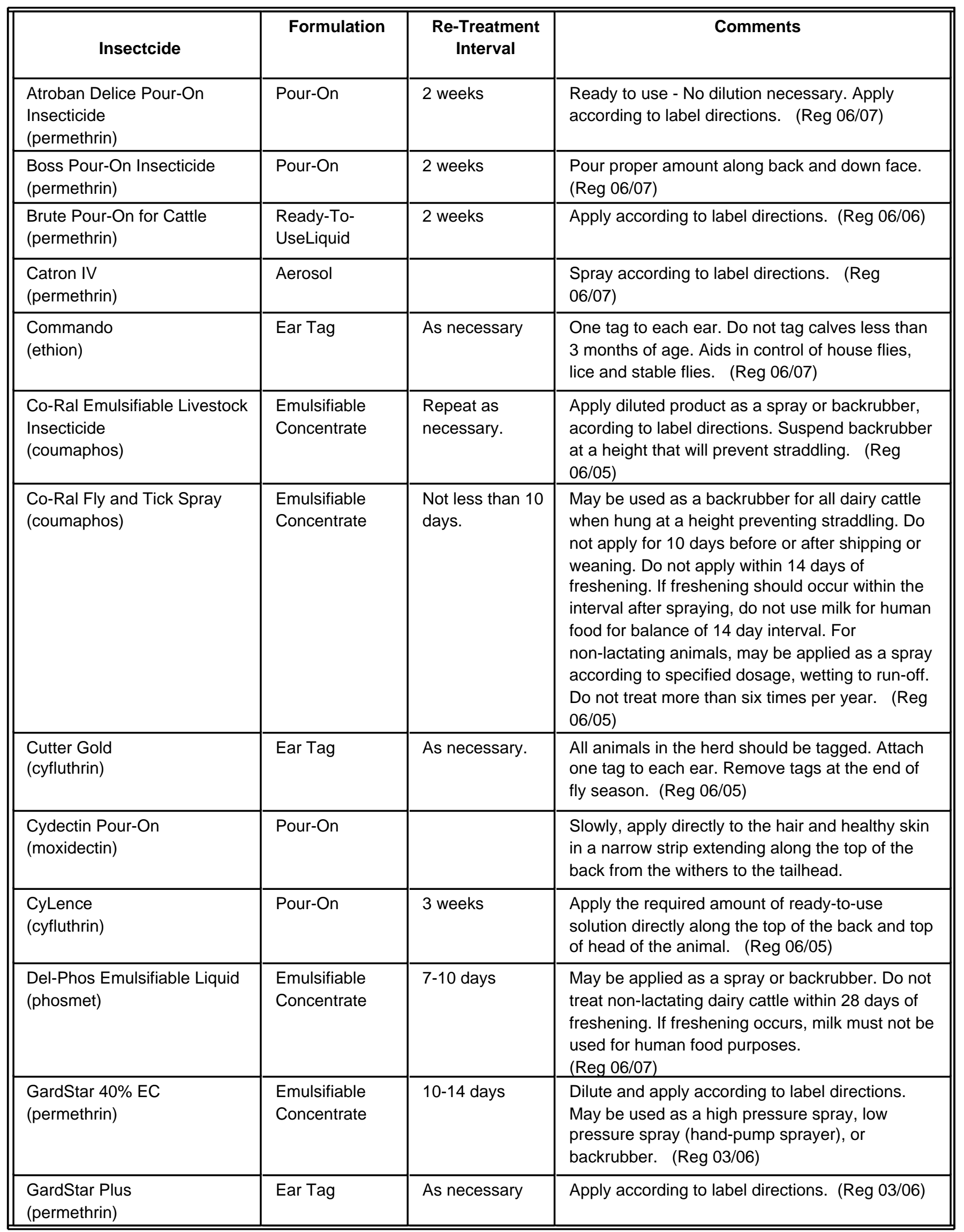


Table 2. Registered Insecticides for Specific Pests of Dairy Cattle.

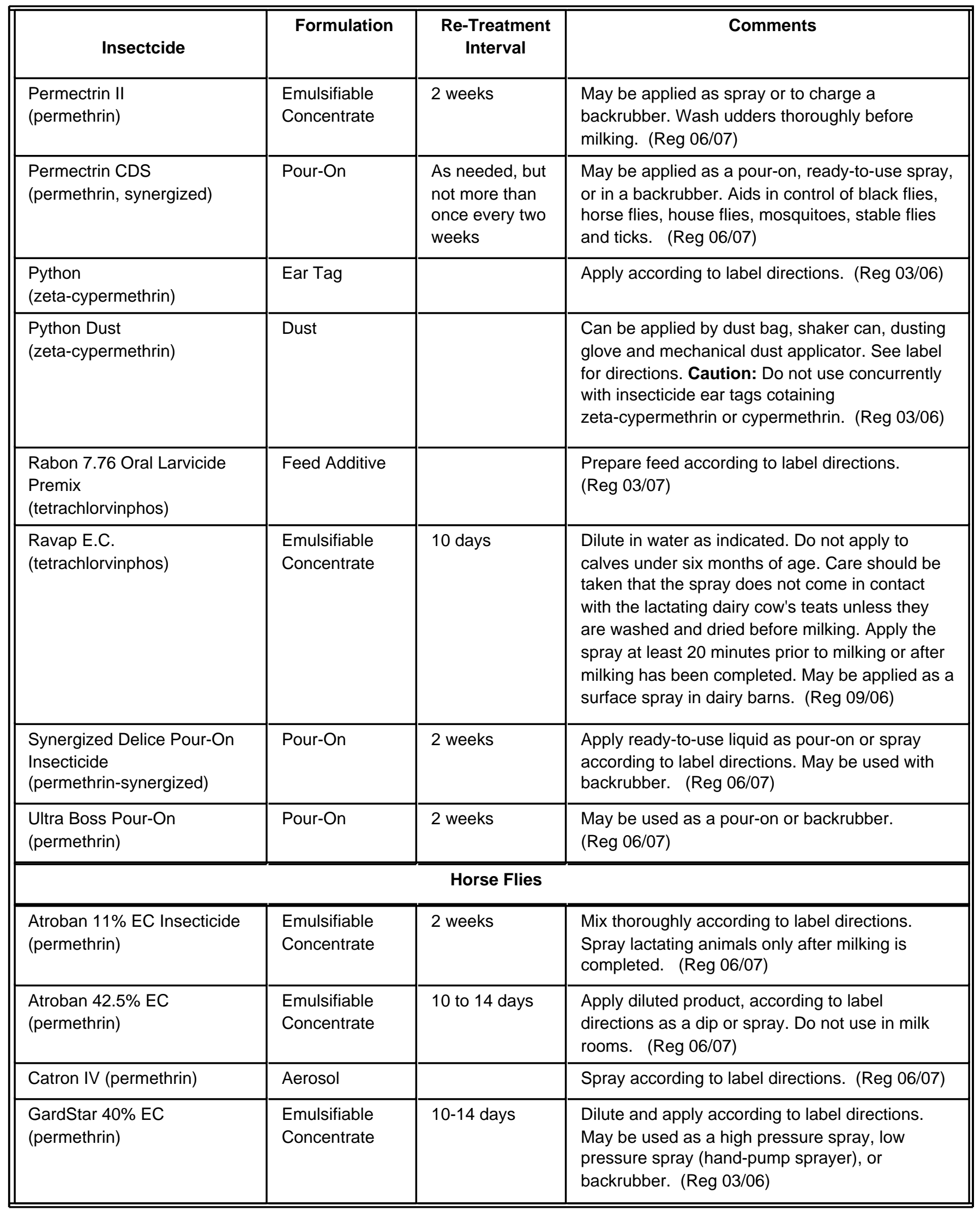


Table 2. Registered Insecticides for Specific Pests of Dairy Cattle.

\begin{tabular}{|c|c|c|c|}
\hline Insectcide & Formulation & $\begin{array}{l}\text { Re-Treatment } \\
\text { Interval }\end{array}$ & Comments \\
\hline $\begin{array}{l}\text { Atroban } 11 \% \text { EC Insecticide } \\
\text { (permethrin) }\end{array}$ & $\begin{array}{l}\text { Emulsifiable } \\
\text { Concentrate }\end{array}$ & 2 weeks & $\begin{array}{l}\text { Mix thoroughly according to label directions. } \\
\text { Spray lactating animals only after milking is } \\
\text { completed. (Reg 06/07) }\end{array}$ \\
\hline $\begin{array}{l}\text { Atroban } 42.5 \% \mathrm{EC} \\
\text { (permethrin) }\end{array}$ & $\begin{array}{l}\text { Emulsifiable } \\
\text { Concentrate }\end{array}$ & 10 to 14 days & $\begin{array}{l}\text { Apply diluted product, according to label } \\
\text { directions as a dip or spray. Do not use in milk } \\
\text { rooms. (Reg 06/07) }\end{array}$ \\
\hline $\begin{array}{l}\text { GardStar } 40 \% \text { EC } \\
\text { (permethrin) }\end{array}$ & $\begin{array}{l}\text { Emulsifiable } \\
\text { Concentrate }\end{array}$ & $10-14$ days & $\begin{array}{l}\text { Dilute and apply according to label directions. } \\
\text { May be used as a high pressure spray, low } \\
\text { pressure spray (hand-pump sprayer), or } \\
\text { backrubber. (Reg 03/06) }\end{array}$ \\
\hline $\begin{array}{l}\text { Rabon } 7.76 \text { Oral Larvicide } \\
\text { Premix (tetrachlorvinphos) }\end{array}$ & Feed Additive & & $\begin{array}{l}\text { Prepare feed according to label directions. } \\
\text { (Reg 03/07) }\end{array}$ \\
\hline \multicolumn{4}{|c|}{ Lice } \\
\hline $\begin{array}{l}\text { Atroban } 11 \% \text { EC Insecticide } \\
\text { (permethrin) }\end{array}$ & $\begin{array}{l}\text { Emulsifiable } \\
\text { Concentrate }\end{array}$ & 2 weeks & $\begin{array}{l}\text { Mix thoroughly according to label directions. } \\
\text { Spray lactating animals only after milking is } \\
\text { completed. (Reg 06/07) }\end{array}$ \\
\hline Boss Pour-On Insecticide & Pour-On & 2 weeks & $\begin{array}{l}\text { Pour proper amount along back and down face. } \\
\text { For optimum lice control, two treatments at } 14 \\
\text { day intervals are recommended. (Reg 06/07) }\end{array}$ \\
\hline $\begin{array}{l}\text { Brute Pour-On for Cattle } \\
\text { (permethrin) }\end{array}$ & $\begin{array}{l}\text { Ready-To-Use } \\
\text { Liquid }\end{array}$ & 2 weeks & Apply according to label directions. (Reg 06/06) \\
\hline Catron IV (permethrin) & Aerosol & $\begin{array}{l}3 \text { weeks, if } \\
\text { required }\end{array}$ & $\begin{array}{l}\text { For blood-sucking lice, apply to the infested } \\
\text { areas of the animal using a stiff brush to get the } \\
\text { spray to the base of the hair. (Reg 06/07) }\end{array}$ \\
\hline $\begin{array}{l}\text { Co-Ral Emulsifiable Livestock } \\
\text { Insecticide (coumaphos) }\end{array}$ & $\begin{array}{l}\text { Emulsifiable } \\
\text { Concentrate }\end{array}$ & $\begin{array}{l}\text { Repeat as } \\
\text { necessary }\end{array}$ & $\begin{array}{l}\text { Apply diluted product as a spray or backrubber, } \\
\text { acording to label directions. Suspend backrubber } \\
\text { at a height that will prevent straddling. (Reg } \\
06 / 05 \text { ) }\end{array}$ \\
\hline
\end{tabular}


Table 2. Registered Insecticides for Specific Pests of Dairy Cattle.

\begin{tabular}{|c|c|c|c|}
\hline Insectcide & Formulation & $\begin{array}{l}\text { Re-Treatment } \\
\text { Interval }\end{array}$ & Comments \\
\hline CyLence (cyfluthrin) & Pour-On & 3 weeks & $\begin{array}{l}\text { Apply the required amount of ready-to-use } \\
\text { solution directly along the top of the back and top } \\
\text { of head of the animal. (Reg 06/05) }\end{array}$ \\
\hline $\begin{array}{l}\text { Del-Phos Emulsifiable Liquid } \\
\text { (phosmet) }\end{array}$ & $\begin{array}{l}\text { Emulsifiable } \\
\text { Concentrate }\end{array}$ & $7-10$ days & $\begin{array}{l}\text { May be applied as a spray or backrubber. Do not } \\
\text { treat non-lactating dairy cattle within } 28 \text { days of } \\
\text { freshening. If freshening occurs, milk must not be } \\
\text { used for human food purposes. } \\
\text { (Reg 06/07) }\end{array}$ \\
\hline $\begin{array}{l}\text { GardStar } 40 \% \text { EC } \\
\text { (permethrin) }\end{array}$ & $\begin{array}{l}\text { Emulsifiable } \\
\text { Concentrate }\end{array}$ & 10-14 days & $\begin{array}{l}\text { Dilute and apply according to label directions. } \\
\text { May be used as a high pressure spray, low } \\
\text { pressure spray (hand-pump sprayer), or } \\
\text { backrubber. (Reg 03/06) }\end{array}$ \\
\hline $\begin{array}{l}\text { Permectrin CDS } \\
\text { (permethrin, synergized) }\end{array}$ & Pour-On & $\begin{array}{l}\text { As needed, but } \\
\text { not more than } \\
\text { once every two } \\
\text { weeks }\end{array}$ & $\begin{array}{l}\text { May be applied as a pour-on, ready-to-use spray, } \\
\text { or in a backrubber. Aids in control of black flies, } \\
\text { horse flies, house flies, mosquitoes, stable flies } \\
\text { and ticks. (Reg 06/07) }\end{array}$ \\
\hline Python (zeta-cypermethrin) & Ear Tag & & $\begin{array}{l}\text { Apply according to label directions. (Reg } \\
03 / 06 \text { ) }\end{array}$ \\
\hline $\begin{array}{l}\text { Python Dust } \\
\text { (zeta-cypermethrin) }\end{array}$ & Dust & & $\begin{array}{l}\text { Can be applied by dust bag, shaker can, dusting } \\
\text { glove and mechanical dust applicator. See label } \\
\text { for directions. Caution: Do not use concurrently } \\
\text { with insecticide ear tags containing } \\
\text { zeta-cypermethrin or cypermethrin. (Reg 03/06) }\end{array}$ \\
\hline
\end{tabular}


Table 2. Registered Insecticides for Specific Pests of Dairy Cattle.

\begin{tabular}{|c|c|c|c|}
\hline Insectcide & Formulation & $\begin{array}{l}\text { Re-Treatment } \\
\text { Interval }\end{array}$ & Comments \\
\hline $\begin{array}{l}\text { Ravap E.C. } \\
\text { (tetrachlorvinphos) }\end{array}$ & $\begin{array}{l}\text { Emulsifiable } \\
\text { Concentrate }\end{array}$ & & $\begin{array}{l}\text { Dilute in water as indicated. Do not apply to } \\
\text { calves under six months of age. Care should be } \\
\text { taken that the spray does not come in contact } \\
\text { with the lactating dairy cow's teats unless they } \\
\text { are washed and dried before milking. Apply the } \\
\text { spray at least } 20 \text { minutes prior to milking or after } \\
\text { milking has been completed. May be applied as a } \\
\text { surface spray in dairy barns. (Reg 09/06) }\end{array}$ \\
\hline $\begin{array}{l}\text { Synergized Delice Pour-On } \\
\text { Insecticide } \\
\text { (permethrin-synergized) }\end{array}$ & Pour-On & 2 weeks & $\begin{array}{l}\text { Apply ready-to-use liquid as pour-on or spray } \\
\text { according to label directions. May be used with } \\
\text { backrubber. (Reg 06/07) }\end{array}$ \\
\hline $\begin{array}{l}\text { Ultra Boss Pour-On } \\
\text { (permethrin) }\end{array}$ & Pour-On & 2 weeks & $\begin{array}{l}\text { May be used as a pour-on or backrubber. } \\
\text { (Reg 06/07) }\end{array}$ \\
\hline \multicolumn{4}{|c|}{ Mites } \\
\hline $\begin{array}{l}\text { Atroban } 42.5 \% \text { EC } \\
\text { (permethrin) }\end{array}$ & $\begin{array}{l}\text { Emulsifiable } \\
\text { Concentrate }\end{array}$ & 10 to 14 days & $\begin{array}{l}\text { Apply diluted product, according to label } \\
\text { directions as a dip or spray. Do not use in milk } \\
\text { rooms. (Reg 06/07) }\end{array}$ \\
\hline $\begin{array}{l}\text { Permectrin II } \\
\text { (permethrin) }\end{array}$ & $\begin{array}{l}\text { Emulsifiable } \\
\text { Concentrate }\end{array}$ & 2 weeks & $\begin{array}{l}\text { May be applied as spray or to charge a } \\
\text { backrubber. Wash udders thoroughly before } \\
\text { milking. (Reg 06/07) }\end{array}$ \\
\hline \multicolumn{4}{|c|}{ Mites (Mange) } \\
\hline $\begin{array}{l}\text { Atroban } 11 \% \text { EC Insecticide } \\
\text { (permethrin) }\end{array}$ & $\begin{array}{l}\text { Emulsifiable } \\
\text { Concentrate }\end{array}$ & 2 weeks & $\begin{array}{l}\text { Mix thoroughly according to label directions. } \\
\text { Spray lactating animals only after milking is } \\
\text { completed. (Reg 06/07) }\end{array}$ \\
\hline $\begin{array}{l}\text { Del-Phos Emulsifiable Liquid } \\
\text { (phosmet) }\end{array}$ & $\begin{array}{l}\text { Emulsifiable } \\
\text { Concentrate }\end{array}$ & 7-10 days & $\begin{array}{l}\text { May be applied as a spray or backrubber. Do not } \\
\text { treat non-lactating dairy cattle within } 28 \text { days of } \\
\text { freshening. If freshening occurs, milk must not be } \\
\text { used for human food purposes. } \\
\text { (Reg 06/07) }\end{array}$ \\
\hline $\begin{array}{l}\text { GardStar } 40 \% \text { EC } \\
\text { (permethrin) }\end{array}$ & $\begin{array}{l}\text { Emulsifiable } \\
\text { Concentrate }\end{array}$ & 10-14 days & $\begin{array}{l}\text { Dilute and apply according to label directions. } \\
\text { May be used as a high pressure spray, low } \\
\text { pressure spray (hand-pump sprayer), or } \\
\text { backrubber. (Reg 03/06) }\end{array}$ \\
\hline \multicolumn{4}{|c|}{ Mites (Scabies) } \\
\hline $\begin{array}{l}\text { Atroban } 11 \% \text { EC Insecticide } \\
\text { (permethrin) }\end{array}$ & $\begin{array}{l}\text { Emulsifiable } \\
\text { Concentrate }\end{array}$ & 2 weeks & $\begin{array}{l}\text { Mix thoroughly according to label directions. } \\
\text { Spray lactating animals only after milking is } \\
\text { completed. (Reg 06/07) }\end{array}$ \\
\hline
\end{tabular}


Table 2. Registered Insecticides for Specific Pests of Dairy Cattle.

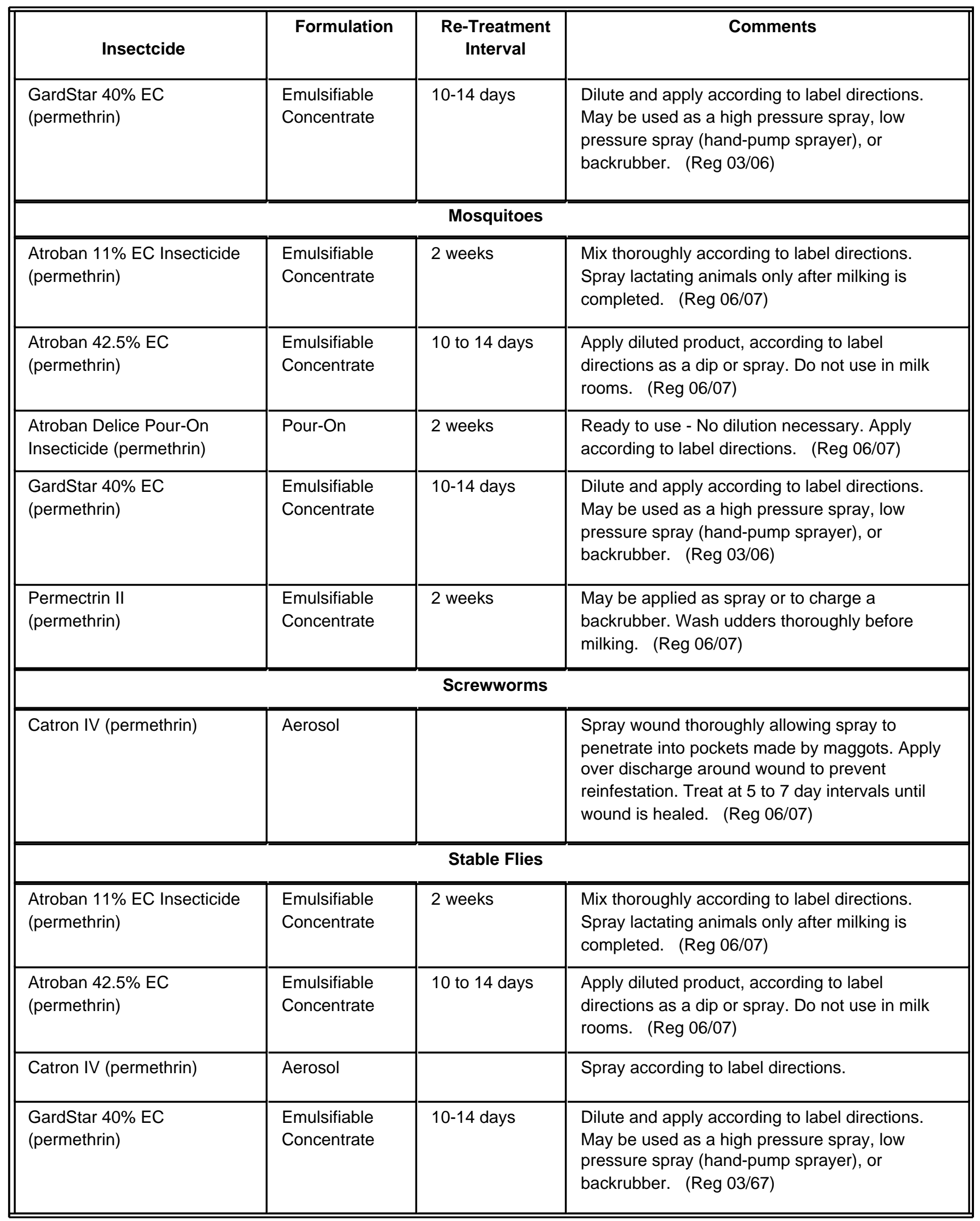


Table 2. Registered Insecticides for Specific Pests of Dairy Cattle.

\begin{tabular}{|c|c|c|c|}
\hline Insectcide & Formulation & $\begin{array}{l}\text { Re-Treatment } \\
\text { Interval }\end{array}$ & Comments \\
\hline $\begin{array}{l}\text { Permectrin II } \\
\text { (permethrin) }\end{array}$ & $\begin{array}{l}\text { Emulsifiable } \\
\text { Concentrate }\end{array}$ & 2 weeks & $\begin{array}{l}\text { May be applied as spray or to charge a } \\
\text { backrubber. Wash udders thoroughly before } \\
\text { milking. (Reg 06/07) }\end{array}$ \\
\hline $\begin{array}{l}\text { Rabon } 7.76 \text { Oral Larvicide } \\
\text { Premix (tetrachlorvinphos) }\end{array}$ & Feed Additive & & $\begin{array}{l}\text { Prepare feed according to label directions. } \\
\text { (Reg 03/07) }\end{array}$ \\
\hline \multicolumn{4}{|c|}{ Ticks } \\
\hline $\begin{array}{l}\text { Atroban } 11 \% \text { EC Insecticide } \\
\text { (permethrin) }\end{array}$ & $\begin{array}{l}\text { Emulsifiable } \\
\text { Concentrate }\end{array}$ & 2 weeks & $\begin{array}{l}\text { Mix thoroughly according to label directions. } \\
\text { Spray lactating animals only after milking is } \\
\text { completed. (Reg 06/07) }\end{array}$ \\
\hline $\begin{array}{l}\text { Atroban } 42.5 \% \text { EC } \\
\text { (permethrin) }\end{array}$ & $\begin{array}{l}\text { Emulsifiable } \\
\text { Concentrate }\end{array}$ & 10 to 14 days & $\begin{array}{l}\text { Apply diluted product, according to label } \\
\text { directions as a dip or spray. Do not use in milk } \\
\text { rooms. (Reg 06/07) }\end{array}$ \\
\hline $\begin{array}{l}\text { Atroban Delice Pour-On } \\
\text { Insecticide (permethrin) }\end{array}$ & Pour-On & 2 weeks & $\begin{array}{l}\text { Ready to use - No dilution necessary. Apply } \\
\text { according to label directions. (Reg 06/07) }\end{array}$ \\
\hline $\begin{array}{l}\text { Co-Ral Fly and Tick Spray } \\
\text { (coumaphos) }\end{array}$ & $\begin{array}{l}\text { Emulsifiable } \\
\text { Concentrate }\end{array}$ & 10 days & $\begin{array}{l}\text { May be used as a backrubber for all dairy cattle } \\
\text { when hung at a height preventing straddling. Do } \\
\text { not apply for } 10 \text { days before or after shipping or } \\
\text { weaning. Do not apply within } 14 \text { days of } \\
\text { freshening. If freshening should occur within the } \\
\text { interval after spraying, do not use milk for human } \\
\text { food for balance of } 14 \text { day interval. For } \\
\text { non-lactating animals, may be applied as a spray } \\
\text { according to specified dosage, wetting to run-off. } \\
\text { Do not treat more than six times per year. (Reg } \\
06 / 05 \text { ) }\end{array}$ \\
\hline $\begin{array}{l}\text { GardStar } 40 \% \text { EC } \\
\text { (permethrin) }\end{array}$ & $\begin{array}{l}\text { Emulsifiable } \\
\text { Concentrate }\end{array}$ & 10-14 days & $\begin{array}{l}\text { Dilute and apply according to label directions. } \\
\text { May be used as a high pressure spray, low } \\
\text { pressure spray (hand-pump sprayer), or } \\
\text { backrubber. (Reg 03/06) }\end{array}$ \\
\hline $\begin{array}{l}\text { Permectrin II } \\
\text { (permethrin) }\end{array}$ & $\begin{array}{l}\text { Emulsifiable } \\
\text { Concentrate }\end{array}$ & 2 weeks & $\begin{array}{l}\text { May be applied as spray or to charge a } \\
\text { backrubber. Wash udders thoroughly before } \\
\text { milking. (Reg 06/07) }\end{array}$ \\
\hline $\begin{array}{l}\text { Python Dust } \\
\text { (zeta-cypermehtrin) }\end{array}$ & Dust & & $\begin{array}{l}\text { Can be applied by dust bag, shaker can, dusting } \\
\text { glove and mechanical dust applicator. See label } \\
\text { for directions. Caution: Do not use concurrently } \\
\text { with insecticide ear tags containing } \\
\text { zeta-cypermethrin or cypermethrin. (Reg 03/06) }\end{array}$ \\
\hline \multicolumn{4}{|c|}{ Ticks (Ear) } \\
\hline Commando (ethion) & Ear Tag & As necessary & $\begin{array}{l}\text { One tag to each ear. Do not tag calves less than } \\
3 \text { months of age. (Reg 06/07) }\end{array}$ \\
\hline \multicolumn{4}{|c|}{ Ticks (Gulf Coast) } \\
\hline Catron IV (permethrin) & Aerosol & As necessary & $\begin{array}{l}\text { Spray directly onto ticks on outer surface of } \\
\text { animal's ear. (Reg 06/07) }\end{array}$ \\
\hline
\end{tabular}


Table 2. Registered Insecticides for Specific Pests of Dairy Cattle.

\begin{tabular}{|c|c|c|c|}
\hline Insectcide & Formulation & $\begin{array}{l}\text { Re-Treatment } \\
\text { Interval }\end{array}$ & Comments \\
\hline Cutter Gold (cyfluthrin) & Ear Tag & As necessary & $\begin{array}{l}\text { All animals in the herd should be taged. Attach } \\
\text { one tag to each ear. Remove tags at the end of } \\
\text { fly season. (Reg 06/05) }\end{array}$ \\
\hline $\begin{array}{l}\text { Del-Phos Emulsifiable Liquid } \\
\text { (phosmet) }\end{array}$ & $\begin{array}{l}\text { Emulsifiable } \\
\text { Concentrate }\end{array}$ & 7-10 days & $\begin{array}{l}\text { May be applied as a spray or backrubber. Do not } \\
\text { treat non-lactating dairy cattle within } 28 \text { days of } \\
\text { freshening. If freshening occurs, milk must not be } \\
\text { used for human food purposes. } \\
\text { (Reg 06/07) }\end{array}$ \\
\hline GardStar Plus (permethrin) & Ear Tag & As necessary & Apply according to label directions. (Reg 03/06) \\
\hline Python (zeta-cypermethrin) & Ear Tag & & Apply according to label directions. (Reg 03/06) \\
\hline \multicolumn{4}{|c|}{ Ticks (Lone Star) } \\
\hline $\begin{array}{l}\text { Del-Phos Emulsifiable Liquid } \\
\text { (phosmet) }\end{array}$ & $\begin{array}{l}\text { Emulsifiable } \\
\text { Concentrate }\end{array}$ & 7-10 days & $\begin{array}{l}\text { May be applied as a spray or backrubber. Do not } \\
\text { treat non-lactating dairy cattle within } 28 \text { days of } \\
\text { freshening. If freshening occurs, milk must not be } \\
\text { used for human food purposes. } \\
\text { (Reg } 06 / 07 \text { ) }\end{array}$ \\
\hline $\begin{array}{l}\text { Ravap } \\
\text { E.C.(tetrachlorvinphos) }\end{array}$ & $\begin{array}{l}\text { Emulsifiable } \\
\text { Concentrate }\end{array}$ & 10 days & $\begin{array}{l}\text { Dilute in water as indicated. Do not apply to } \\
\text { calves under six months of age. Care should be } \\
\text { taken that the spray does not come in contact } \\
\text { with the lactating dairy cow's teats unless they } \\
\text { are washed and dried before milking. Apply the } \\
\text { spray at least } 20 \text { minutes prior to milking or after } \\
\text { milking has been completed. May be applied as a } \\
\text { surface spray in dairy barns. (Reg 09/06) }\end{array}$ \\
\hline \multicolumn{4}{|c|}{ Ticks (Spinose Ear) } \\
\hline Catron IV (permethrin) & Aerosol & As necessary & $\begin{array}{l}\text { Spray downward directly into animal's ear. } \\
\text { (Reg 06/07) }\end{array}$ \\
\hline Cutter Gold (cyfluthrin) & Ear Tag & As necessary & $\begin{array}{l}\text { All animals in the herd should be taged. Attach } \\
\text { one tag to each ear. Remove tags at the end of } \\
\text { fly season. (Reg 06/05) }\end{array}$ \\
\hline GardStar Plus (permethrin) & Ear Tag & As necessary & Apply according to label directions. (Reg 03/06) \\
\hline Python (zeta-cypermethrin) & Ear Tag & & Apply according to label directions. (Reg 03/06) \\
\hline \multicolumn{4}{|c|}{ Ticks (Winter) } \\
\hline $\begin{array}{l}\text { Del-Phos Emulsifiable Liquid } \\
\text { (phosmet) }\end{array}$ & $\begin{array}{l}\text { Emulsifiable } \\
\text { Concentrate }\end{array}$ & 7-10 days & $\begin{array}{l}\text { May be applied as a spray or backrubber. Do not } \\
\text { treat non-lactating dairy cattle within } 28 \text { days of } \\
\text { freshening. If freshening occurs, milk must not be } \\
\text { used for human food purposes. } \\
\text { (Reg 06/07) }\end{array}$ \\
\hline
\end{tabular}


Table 3. Registered Insecticides for Specific Pests on Non-Lactating Dairy Cattle only.

\begin{tabular}{|c|c|c|c|}
\hline Insectcide & Formulation & $\begin{array}{l}\text { Re-Treatment } \\
\text { Interval }\end{array}$ & Comments \\
\hline \multicolumn{4}{|c|}{ Horn Flies } \\
\hline Co-Ral Plus (coumaphos) & Ear Tag & & $\begin{array}{l}\text { All mature animals in the herd should be tagged. } \\
\text { Calves less than } 3 \text { months of age should not be } \\
\text { tagged. Remove tags at end of fly season. } \\
\text { (Reg 06/05) }\end{array}$ \\
\hline Cutter 1 (diazinon) & Ear Tag & As necessary & $\begin{array}{l}\text { For optimum control attach one tag to each ear. } \\
\text { Calves less than } 3 \text { months of age should not be } \\
\text { tagged. Remove tags prior to slaughter. } \\
\text { (Reg 06/05) }\end{array}$ \\
\hline $\begin{array}{l}\text { CyLence Ultra } \\
\text { (beta-cyfluthrin) }\end{array}$ & Ear Tag & As necessary & $\begin{array}{l}\text { All mature animals in the herd should be tagged. } \\
\text { For optimum control attach one tag to each ear. } \\
\text { Calves less than } 3 \text { months of age should not be } \\
\text { tagged. Remove tags prior to slaughter. } \\
\text { (Reg 06/05) }\end{array}$ \\
\hline Optimizer (diazinon) & Ear Tag & & $\begin{array}{l}\text { Attach two tags per animal for optimum control. } \\
\text { All animals in herd should be tagged. Remove } \\
\text { tags at end of fly and lice seasons. (Reg 03/06) }\end{array}$ \\
\hline Patriot (diazinon) & Ear Tag & As necessary & $\begin{array}{l}\text { Attach one tag to each ear. Do not tag claves } \\
\text { less than } 3 \text { months of age. Aids in control of } \\
\text { house flies, lice and stable flies. Remove tags } \\
\text { prior to slaughter. (Reg 06/07) }\end{array}$ \\
\hline $\begin{array}{l}\text { Prolate/Lintox-HD } \\
\text { (phosmet) }\end{array}$ & $\begin{array}{l}\text { Emulsifiable } \\
\text { Concentrate }\end{array}$ & $\begin{array}{l}7-10 \text { days as } \\
\text { necessary }\end{array}$ & $\begin{array}{l}\text { May be used as spray or with backrubber. Do not } \\
\text { use this product on animals simultaneously or } \\
\text { within a few days before or after treatment with or } \\
\text { exposure to cholinesterase inhibiting drugs, } \\
\text { pesticides, or chemicals. Do not treat sick, } \\
\text { convalescent, stressed, or animals less than } 3 \\
\text { months old. Do not treat non-lactating dairy cattle } \\
\text { within } 28 \text { days of freshening. If freshening should } \\
\text { occur within the } 28 \text { day period after treatment, } \\
\text { that milk must not be used as human food. (Reg } \\
\text { 12/05) }\end{array}$ \\
\hline $\begin{array}{l}\text { Warrior } \\
\text { (diazinon + chlorpyrifos) }\end{array}$ & Ear Tag & & $\begin{array}{l}\text { Apply when pests appear. For optimum control, } \\
\text { apply } 2 \text { tags per animal ( } 1 \text { per ear) for up to } 5 \\
\text { months. All animals in the herd should be tagged. } \\
\text { Do not tag animals less than } 3 \text { months of age. } \\
\text { Remove tags prior to slaughter. } \\
\text { (Reg 03/06) }\end{array}$ \\
\hline \multicolumn{4}{|c|}{ Lice } \\
\hline Optimizer (diazinon) & Ear Tag & & $\begin{array}{l}\text { Attach two tags per animal for optimum control. } \\
\text { All animals in herd should be tagged. Remove } \\
\text { tags at end of fly and lice season. (Reg } 03 / 06 \text { ) }\end{array}$ \\
\hline
\end{tabular}


Table 3. Registered Insecticides for Specific Pests on Non-Lactating Dairy Cattle only.

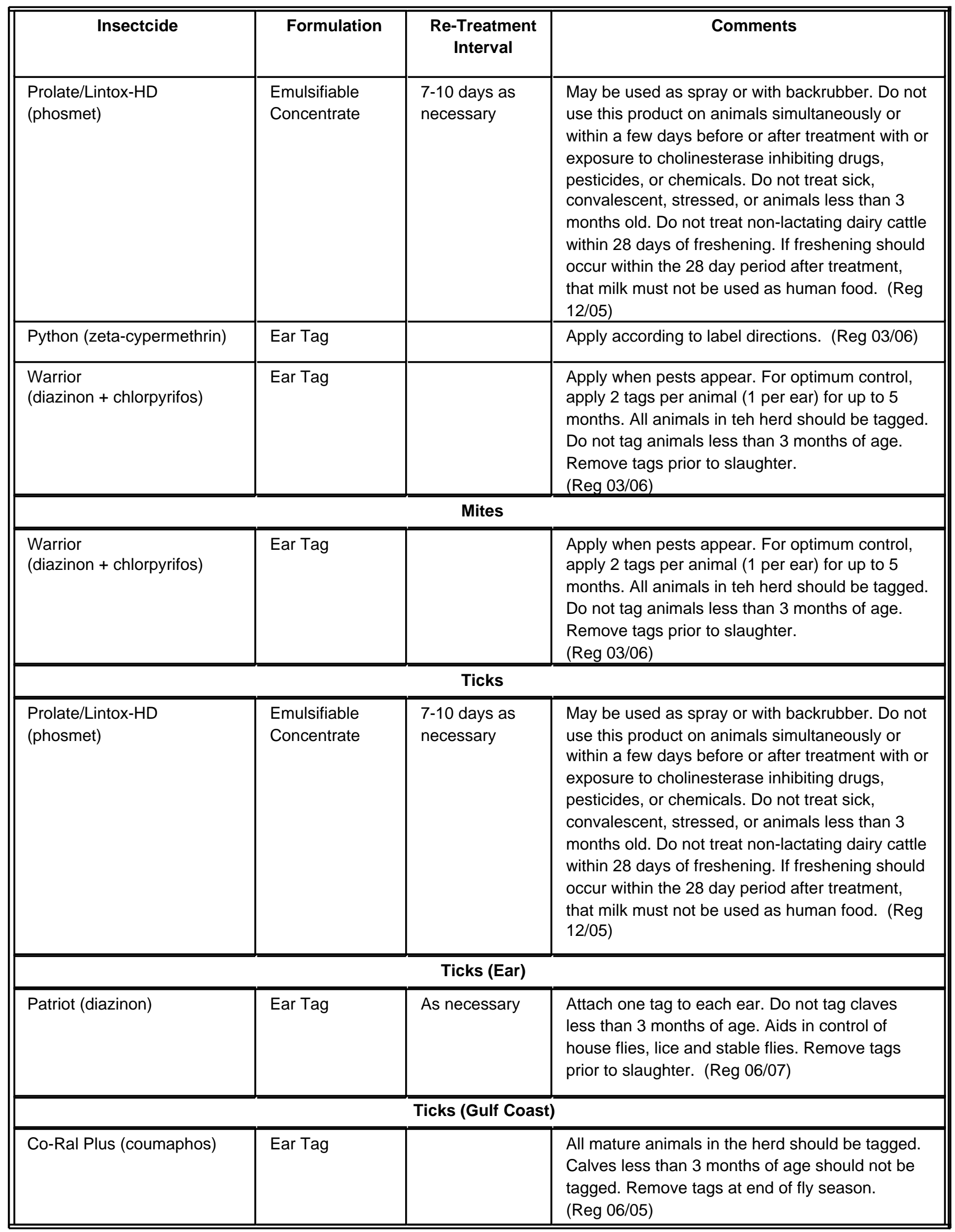


Table 3. Registered Insecticides for Specific Pests on Non-Lactating Dairy Cattle only.

\begin{tabular}{|c|c|c|c|}
\hline Insectcide & Formulation & $\begin{array}{l}\text { Re-Treatment } \\
\text { Interval }\end{array}$ & Comments \\
\hline Cutter 1 (diazinon) & Ear Tag & As necessary & $\begin{array}{l}\text { For optimum control attach one tag to each ear. } \\
\text { Calves less than } 3 \text { months of age should not be } \\
\text { tagged. Remove tags prior to slaughter. } \\
\text { (Reg 06/05) }\end{array}$ \\
\hline $\begin{array}{l}\text { CyLence Ultra } \\
\text { (beta-cyfluthrin) }\end{array}$ & Ear Tag & As necessary & $\begin{array}{l}\text { All mature animals in the herd should be tagged. } \\
\text { For optimum control attach one tag to each ear. } \\
\text { Calves less than } 3 \text { months of age should not be } \\
\text { tagged. Remove tags prior to slaughter. } \\
\text { (Reg 06/05) }\end{array}$ \\
\hline Optimizer (diazinon) & Ear Tag & & $\begin{array}{l}\text { Attach two tags per animal for optimum control. } \\
\text { All animals in herd should be tagged. Remove } \\
\text { tags at end of fly and lice season. (Reg 03/06) }\end{array}$ \\
\hline $\begin{array}{l}\text { Warrior } \\
\text { (diazinon + chlorpyrifos) }\end{array}$ & Ear Tag & & $\begin{array}{l}\text { Apply when pests appear. For optimum control, } \\
\text { apply } 2 \text { tags per animal ( } 1 \text { per ear) for up to } 5 \\
\text { months. All animals in teh herd should be tagged. } \\
\text { Do not tag animals less than } 3 \text { months of age. } \\
\text { Remove tags prior to slaughter. } \\
\text { (Reg 03/06) }\end{array}$ \\
\hline \multicolumn{4}{|c|}{ Ticks (Spinose Ear) } \\
\hline Co-Ral Plus (coumaphos) & Ear Tag & & $\begin{array}{l}\text { All mature animals in the herd should be tagged. } \\
\text { Calves less than } 3 \text { months of age should not be } \\
\text { tagged. Remove tags at end of fly season. } \\
\text { (Reg 06/05) }\end{array}$ \\
\hline Cutter 1 (diazinon) & Ear Tag & As necessary & $\begin{array}{l}\text { For optimum control attach one tag to each ear. } \\
\text { Calves less than } 3 \text { months of age should not be } \\
\text { tagged. Remove tags prior to slaughter. } \\
\text { (Reg 06/05) }\end{array}$ \\
\hline $\begin{array}{l}\text { CyLence Ultra } \\
\text { (beta-cyfluthrin) }\end{array}$ & Ear Tag & As necessary & $\begin{array}{l}\text { All mature animals in the herd should be tagged. } \\
\text { For optimum control attach one tag to each ear. } \\
\text { Calves less than } 3 \text { months of age should not be } \\
\text { tagged. Remove tags prior to slaughter. } \\
\text { (Reg 06/05) }\end{array}$ \\
\hline Optimizer (diazinon) & Ear Tag & & $\begin{array}{l}\text { Attach two tags per animal for optimum control. } \\
\text { All animals in herd should be tagged. Remove } \\
\text { tags at end of fly and lice season. (Reg 03/06) }\end{array}$ \\
\hline $\begin{array}{l}\text { Warrior } \\
\text { (diazinon + chlorpyrifos) }\end{array}$ & Ear Tag & & $\begin{array}{l}\text { Apply when pests appear. For optimum control, } \\
\text { apply } 2 \text { tags per animal ( } 1 \text { per ear) for up to } 5 \\
\text { months. All animals in the herd should be tagged. } \\
\text { Do not tag animals less than } 3 \text { months of age. } \\
\text { Remove tags prior to slaughter. } \\
\text { (Reg 03/06) }\end{array}$ \\
\hline
\end{tabular}

